\title{
COMMENTS
}

\section{SELECTIVE PROSECUTION AND THE FEDERALIZATION OF CRIMINAL LAW: THE NEED FOR MEANINGFUL JUDICIAL REVIEW OF PROSECUTORIAL DISCRETION}

\author{
ROBERT HELLER ${ }^{\dagger}$
}

\section{INTRODUCTION}

On March 9, 1994, Frank Ferris was indicted on one count of possession with intent to distribute cocaine base, or crack-cocaine ("crack"), in violation of 21 U.S.C. $\$ 841$. He was subsequently convicted and sentenced to five years imprisonment." This conviction and sentence was based on a drug sale to an undercover police officer of twenty dollars worth of crack, an amount small enough to have been wrapped in a gum wrapper. ${ }^{2}$ This crime, although prosecuted in federal court, could have been prosecuted in state court under applicable state law. ${ }^{3}$ What motivated federal prosecutors to charge Mr. Ferris in federal court? Perhaps he was part of a larger interstate or international cocaine ring that implicated substantial federal interests. Perhaps he was a recidivist whom prosecutors believed deserved more severe federal penalties. There are a number of rational motivations for prosecuting Mr. Ferris in federal court. Irrational and even unconstitutional motivations, however, are distinct possibilities

† B.A. 1995, J.D. Candidate 1998, University of Pennsylvania. This Comment is dedicated to my parents, Janice and Jack Heller. Without their support and encouragement I would not have had, nor have been able to take advantage of, the academic opportunities afforded to me that have culminated in this Comment. I would also like to thank the University of Pennsylvania for seven years of the finest education, and the Law School faculty and administration in particular who have made my legal education the most rewarding experience of my life.

'See United States v. Ferris, No. 94-5783, 1995 WL 417606, at *1 (4th Cir. July 6, 1995).

\footnotetext{
2 See id.

${ }^{3}$ See VA. CODE ANN. § 18.2-248 (Michie 1996).
} 
as well. ${ }^{4}$ After all, why burden the federal courts with the prosecution of a mere twenty dollar sale of crack?

The story of the federal prosecution of Mr. Ferris indicates a potential problem of federal law enforcement in general, and federal drug law enforcement in particular. Relatively insignificant crimes that affect purely local interests potentially rise to the level of federal crimes. This is a recent phenomenon in American criminal law. ${ }^{5}$ Throughout much of American history, the regulation of criminal conduct was principally the province of the governments of the several states. This local control of criminal law was, in large part, due to the recognized limited powers of the federal government, a government restrained in its authority by the enumerated powers granted to it in the Constitution. ${ }^{6}$ Policy concerns also dictated local control of the criminal justice system, as state governments were viewed as the political bodies best suited for protecting citizens from the primarily local problem of crime.

As in other areas of the law, however, the changes that came with the modern era forever altered the landscape of criminal law, as the federal government began to encroach upon what had been a bastion of state sovereignty. ${ }^{8}$ Massive economic expansion forced the federal government to play a larger role in American society, and the arena

${ }^{4}$ Mr. Ferris never challenged the decision to prosecute him in federal court based on unconstitutional motives. Because of the small quantity of drugs involved, however, his case is a perfect example of the potential for prosecutorial abuse that is the focus of this Comment. See infra notes 16-20 and accompanying text.

${ }^{5}$ See, e.g., Gerald G. Ashdown, Federalism, Federalization, and the Politics of Crime, 98 W. VA. L. REV. 789, 789 (1996) ("Jurisdiction over criminal enforcement has been, throughout the history of American law, primarily local."); Sam J. Ervin, III, The Federalization of State Crimes: Some Observations and Reflections, 98 W. VA. L. REV. 761, 761 (1996) (noting that "Congress seems intent on 'federalizing' more and more criminal offenses that have been historically tried in state courts").

${ }^{6}$ See Ashdown, supra note 5, at 790 ("The United States Constitution granted relatively little criminal law enforcement authority to the newly created federal government....").

${ }^{7}$ See Jamie S. Gorelick \& Harry Litman, Prosecutorial Discretion and the Federalization Debate, 46 HASTINGS L.J. 967, 968 (1995) (noting that some critics of the increasing trend in federalizing criminal law are principally concerned with recent crime legislation inappropriately infringing upon federalism interests by taking "matters traditionally of local concern out of the hands of local officials").

${ }^{8}$ For a more complete historical summary of the federal government's role in criminal law, see Sara Sun Beale, Reporter's Draft for the Working Group on Principles to Use When Considering the Federalization of Criminal Law, 46 HASTINGS L.J. 1277, 1278-94 (1995). 
of criminal law was no exception. ${ }^{9}$ The post-New Deal expansive interpretation of the Commerce Clause rendered the constitutional barrier to an increased role for the federal government largely nonexistent. ${ }^{10}$ As "the crime problem" invaded the national consciousness to an unprecedented degree, especially in the past quarter-century, the "federalization" of crime has continued on an even more massive scale."

${ }^{9}$ See Ashdown, supra note 5, at 790 ("[1]t was not until mobility and vast resources led to geographic and economic expansion that federal influence [in criminal law] began to be felt").

${ }^{10}$ Although on its face, the Commerce Clause grants Congress the limited power "[t]o regulate Commerce with foreign Nations, and among the several States, and with the Indian Tribes," U.S. CONST. art. I, $\S 8, \mathrm{cl} .3$, the modern interpretation of this language is that the federal government may regulate any activity, even if purely local in nature, as long as "it exerts a substantial economic effect on interstate commerce, and this irrespective of whether such effect is what might at some earlier time have been defined as 'direct' or 'indirect." Wickard v. Filburn, 317 U.S. 111, 125 (1942). This "affecting commerce" rationale has provided constitutional support for countless federal criminal statutes. See, e.g., Scarborough v. United States, 431 U.S. 563 (1977) (holding that the firearm possession provisions of the Omnibus Crime Control and Safe Streets Act of 1968 were constitutionally permissible exercises of congressional powers under the Commerce Clause); Perez v. United States, 402 U.S. 146, 154 (1971) (same holding with respect to the "loan shark" provisions of the Consumer Credit Protection Act of 1964 given the fact that "[e]xtortionate credit transactions ... may in the judgment of Congress affect interstate commerce"). But see United States v. Lopez, 115 S. Ct. 1624 (1995) (holding that the Gun-Free School Zones Act of 1990, which made it a federal crime to possess a firearm within designated school zones, exceeded congressional powers pursuant to the Commerce Clause).

Although Lopez suggests a possible narrowing of congressional Commerce Clause powers, the Court's decision can be interpreted as resting on the fact that the Act contained no congressional findings regarding the actual effects on interstate commerce of gun possession in schools, and thus the decision should not be viewed as a broad constitutional attack on federal criminal legislation. See id. at 1631-32 ("We agree... that Congress normally is not required to make formal findings as to the substantial burdens that an activity has on interstate commerce. But to the extent that congressional findings would enable us to evaluate the legislative judgment that the activity in question substantially affected interstate commerce, even though no such substantial effect was visible to the naked eye, they are lacking here." (citation omitted)). But see Ashdown, supra note 5, at 808 (arguing that Lopez "is clearly a substantive, principle-based decision, and not a narrow procedural holding based on the lack of congressional findings"). Professor Ashdown notes, however, that subsequent to the Lopez decision, the lower federal courts have been "terribly stingy" in applying the Supreme Court's decision. Id. at $809 \&$ n.113 (listing 34 reported lower federal court decisions that refused to apply the Lopez holding and only four reported decisions that have applied the Court's alleged limitation on congressional Commerce Clause power). This may suggest that Lopez, at least until the Supreme Court clarifies the scope of its holding, does indeed rest on narrow procedural grounds.

"Prior to the passage of the 1994 Crime Bill, estimates placed the number of federal crimes at over 3,000. See Sara Sun Beale, Too Many and Yet Too Few: New Principles to Define the Proper Limits for Federal Criminal Jurisdiction, 46 HASTINGS L.J. 979, 980 \& 
Most of the federal expansion into the criminal law arena has not been at the expense of state criminal law. Federal criminal law, rather than preempting state law, largely supplements preexisting state prohibitions. ${ }^{12}$ Thus, conduct that constitutes a federal crime in many cases "permit[s] dual jurisdiction by both federal and state authorities." ${ }^{\text {13 }}$ The most visible example of this concurrent jurisdiction, both in terms of public awareness and the sheer number of cases prosecuted, is in the area of illegal drugs. ${ }^{14}$ An accused drug offender is subject to federal prosecution, state prosecution, or both, for the same criminal incident. ${ }^{15}$ Because of the wide disparity in sentencing between federal and state drug statutes, the decision whether to prosecute federally takes on crucial importance. Simply stated, when a U.S. Attorney decides to prosecute a drug offender in federal court, rather than allow a state district attorney to prosecute the case in state court, the offender will ordinarily be subject to more severe punishment than similarly situated offenders who are prosecuted in state court. ${ }^{16}$

n.10 (1995) (citing Hon. Roger J. Miner, Crime and Punishment in the Federal Courts, 43 SYRACUSE L. REV. 681, 681 (1992)). This expansion of federal criminal law can be directly attributed to the modern-day political climate of "law-and-order, crime control, and generally getting tough on crime." Ashdown, supra note 5, at 806.

12 For example, most of the new federal offenses introduced into the United States Code in the past decade, including in the recently passed Crime Bill, prohibit such conduct as theft of major artwork, failure to pay child support, and drive-by shootings. These types of conduct are all the subjects of state criminal law in addition to federal criminal law. See, e.g, 18 U.S.C. $\$ 668$ (1994) (theft of major artwork); 18 U.S.C. $\$ \S 228$ \& 3563 (b) (1) (1994) (failure to pay child support); 18 U.S.C. $\$ 36$ (1994) (drive-by shootings); see also, e.g., KY. REV. STAT. ANN. \$ 516.110 (Michie 1990) (theft of artwork); 23 PA. CONS. STAT. ANN. $\$ 4345$ (West 1991) (failure to pay child support); ARIZ. REV. STAT. ANN. \$ 13-1209 (West Supp. 1996) (drive-by shootings).

13 Beale, supra note 11 , at 981 .

${ }^{14}$ Cf. Sara Sun Beale, Federal Criminal Caseload/Scope of Federal Criminal Jurisdiction, in REPORT OF THE SUBCOMM. ON WORKLOAD at 7, in 1 FEDERAL COURTS STUDY COMM., WORKING PAPERS AND SUBCOMM. REPORTS JULY 1, 1990 (opining that " $[t]$ he sheer number of drug prosecutions poses a threat to the federal courts' ability to perform their constitutional role [as mainly civil tribunals]").

${ }^{15}$ The potential constitutional violations that occur when a defendant is prosecuted in both state and federal court for the same conduct is beyond the scope of this Comment.

${ }^{16}$ For example, a defendant convicted of possession of 50 grams of crack is subject to a mandatory minimum sentence of 10 years imprisonment under applicable federal law. See 21 U.S.C. $\$ 841$ (b)(1)(A)(iii) (1994). The same defendant is subject to a three-year mandatory minimum sentence if prosecuted in the state courts of California or Pennsylvania. See CAL. HEALTH \& SAFETY CODE $\S 11351.5$ (West 1991); 18 PA. CONS. STAT. ANN. $§ 7508$ (a) (2) (ii) (West Supp. 1996). This sentencing disparity is exacerbated in a number of states because of the availability of parole in many state penal systems, unlike in the federal system. 
Concurrent jurisdiction due to the federalization of criminal law introduces into the criminal justice system a potential for prosecutorial abuse that was not an area of concern when crime was primarily a locally regulated phenomenon. ${ }^{17}$ Prior to the widespread presence of the federal government in the area of criminal law, prosecutorial abuse with regard to the charging decision occurred only when a prosecutor charged a person with a crime despite having no probable cause to believe that person had committed the crime. ${ }^{18}$ Currently, prosecutorial abuse can occur, even if a prosecutor has the requisite probable cause, when a federal prosecutor decides to prosecute a case in federal court based on such constitutionally impermissible motives such as the defendant's race, religion or ethnicity, rather than allow a state prosecutor to proceed with a state prosecution. ${ }^{19}$

17 This potential abuse of prosecutorial power can be partially ameliorated by the limiting of federal encroachment into substantive criminal law, a distinct possibility following the Lopez decision. See supra note 10. This Comment focuses on a particular constitutional abuse made possible by the federalization of criminal law, as well as its coinciding grant of concurrent jurisdiction between states and the federal government that is most relevant in the area of drug offenses. It therefore should be noted that given the obvious interstate and international scope of the drug trade, the Court's decision in Lopez, whether seen as a narrow procedural holding or a broad substantive limitation on congressional Commerce Clause powers, is not a solution to the constitutional problem made possible by such concurrent jurisdiction. See Ashdown, supra note 5, at $810 \mathrm{n} .115$ ("It is unlikely that certain federal statutes will be susceptible to a Commerce Clause challenge: such as the comprehensive drug laws ...."); see also United States v. Leshuk, 65 F.3d 1105 (4th Cir. 1995) (rejecting a Lopez-based Commerce Clause challenge to the Comprehensive Drug Abuse Prevention and Control Act); United States v. Salmiento, 898 F. Supp. 45 (D.P.R. 1995) (rejecting a Lopez-based Commerce Clause challenge to the Drug Free School Zones Act), aff'd sub nom. United States v. Zorrilla , 93 F.3d 7 (1st Cir. 1996); United States v. Gonzalez, 893 F. Supp. 935 (S.D. Cal. 1995) (same holding for distribution of a controlled substance); United States v. Garcia-Salazar, 891 F. Supp. 568 (D. Kan. 1995) (same holding as Salmiento relating to the Drug Free School Zones Act). Thus, existing Commerce Clause jurisprudence does not suggest a solution to the constitutional concerns that are the focus of this Comment.

${ }^{18}$ See Bordenkircher v. Hayes, 434 U.S. 357, 364 (1978) ("[S]o long as the prosecutor has probable cause to believe that the accused committed an offense defined by statute, the decision whether or not to prosecute, and what charge to file or bring before a grand jury, generally rests entirely in his discretion.").

${ }_{19}$ When conduct is both a federal and a state crime, a federal prosecutor's charging decision is a two-part process. First, she must determine if there is probable cause to believe the accused committed the crime defined by the federal statute. This first part of the charging decisionmaking process has long been a potential area of prosecutorial abuse when impermissible criteria such as race enter into the charging process. See infra Part I. Second, she must determine if the particular conduct warrants a federal prosecution, with the understanding that deciding not to pursue a federal prosecution will not mean that the accused will go unpunished given the existence of state law that makes the same conduct a crime. This second part of the charging deci- 
The doctrine of prosecutorial discretion, which presumes that a prosecutor's decisionmaking process is constitutionally valid, is a principle with many legitimate and persuasive justifications. ${ }^{20}$ In United States $v$. Armstrong, ${ }^{21}$ the Supreme Court recently applied this long-standing doctrine $e^{22}$ to the concurrent jurisdiction decisionmaking process a federal prosecutor confronts when an act constitutes both a federal and state crime. ${ }^{23}$ The Armstrong Court reversed a district court's discovery order that would have compelled the U.S. Attorney's Office for the Central District of California to disclose its criteria for bringing a drug prosecution federally. The Court found that such charging decisions fall within recognized prosecutorial discretion and that only a high threshold of evidence that suggests a constitutional violation based on selective prosecution would permit such discovery. ${ }^{24}$

This Comment will argue that the traditional justifications for granting federal prosecutors almost unchecked discretion in making their charging decisions fail to outweigh the important constitutional rights at issue in situations such as the one the Court confronted in Armstrong. Therefore, the need exists for meaningful judicial review

sionmaking process brings with it the same potential for prosecutorial abuse as the first part, that is, by possibly injecting impermissible criteria into the process. See Greg Hollon, Note, After the Federalization Binge: A Civil Liberties Hangover, 31 HARV. C.R.-C.L. L. REV. 499, 504 (1996) (discussing the potential for prosecutorial abuse by U.S. Attorneys that is made possible when a crime is both a federal and state offense, and noting that the "degree to which disparate federal and state sentences are unjust may depend on the motivations underlying a U.S. [A]ttorney's decision to prosecute a specific defendant federally").

${ }_{20}^{20}$ See infra Part II.

21 116 S. Ct. 1480 (1996).

22 For more exhaustive general discussions of the doctrine of prosecutorial discretion, see KENNETH CULP DAVIS, DISCRETIONARY JUSTICE: A PRELIMINARY INQUIRY, 188214 (1969); James Vorenberg, Decent Restraint of Prosecutorial Power, 94 HARV. L. REV. 1521 (1981).

${ }^{23}$ In Armstrong, the defendant, Christopher Lee Armstrong, claimed that he was being prosecuted in federal court rather than state court based on his race. (There were four defendants involved in the Armstrong litigation, but this Comment, for simplicity, will only refer to the named defendant/respondent, Mr. Armstrong.) In federal court, Armstrong faced a sentence of $\mathbf{5 5}$ years to life, though in state court, he would have been subject to a sentence of three to nine years in prison. See Leading Cases, 110 HARV. L. REV. 135, 166 (1996) (citing Brief for Respondents Shelton Auntwan Martin, Aaron Hampton, Christopher Lee Armstrong, and Freddie Mack at 3, Armstrong (No. 95-157), available in 1996 WL 17111).

${ }^{24}$ See infra Part I.C for a more detailed discussion of the facts and the Court's holding in Armstrong as well as the constitutional doctrine of selective prosecution generally. 
of the federal charging decision. ${ }^{25}$ Part I of this Comment will trace the constitutional principle of selective prosecution embodied in the Fourteenth Amendment's Equal Protection Clause. It will demonstrate that the Supreme Court's decision in Armstrong has rendered this doctrine largely moot in an area that is especially susceptible to such constitutional violations. Part II discusses the doctrine of prosecutorial discretion and its commonly stated rationales. It will examine the applicability of the long-standing principle of prosecutorial discretion to the concurrent jurisdiction context brought on by the federalization of criminal law. This Part will argue that there is a need for meaningful judicial review of prosecutorial decisionmaking. This need stems from the failure of the policies that support broad prosecutorial discretion to justify potential infringement on a defendant's constitutional right to enjoy equal protection of the laws. Finally, Part III of this Comment supplies a working model for such meaningful judicial review. This model is premised on the argument that a prosecutor, as a fiduciary of the people, has a judicially enforceable duty in certain situations to answer a defendant's accusations of unconstitutional selective prosecution through discovery mechanisms.

\section{The Constitutional Doctrine of Selective PROSECUTION}

\section{A. Yick Wo v. Hopkins and the Emergence of the Selective Prosecution Doctrine}

In the seminal case of Yick Wo v. Hopkins, ${ }^{26}$ the Supreme Court established the general constitutional principle that the selective enforcement of a facially neutral statute may violate the Equal Protec-

${ }^{25}$ In the context of this Comment, the federal charging decision relates to the second part of a federal prosecutor's decisionmaking process with respect to charging. See supra note 19. Meaningful judicial review occurs when a judge has sufficient evidence to render a decision on a defendant's selective prosecution claim. The level of evidence needed for meaningful judicial review will depend on the relative merits of the particular claim, but will, at times, require that prosecutors make disclosures relevant to the selective prosecution claim through a district court's inherent discovery powers. See Amstrong, 116 S. Ct. at 1492 (Stevens, J., dissenting) (recognizing a district judge's inherent power to order discovery); FED. R. CRIM. P. 16 advisory committee's note (1974) (stating that Rule 16 is "not intended to limit the judge's discretion to order broader discovery in appropriate cases"); see also United States v. Al Jibori, 90 F.3d 22, 25 (2d Cir. 1996) (suggesting that the Armstrong holding "seriously undermines" prior case law holding that the decision to order discovery "lies largely in the trial judge's discretion" (citation omitted)).

118 U.S. 356 (1886). 
tion Clause of the Fourteenth Amendment. ${ }^{27}$ Yick Wo was a challenge to a San Francisco municipal ordinance that required the consent of the board of supervisors in order for a laundry to be operated in wooden buildings. ${ }^{28}$ The evidence demonstrated that while such consent had been freely given to eighty non-Chinese applicants, twohundred similarly situated Chinese applicants had been denied the necessary consent by the board of supervisors. ${ }^{29}$ In finding that the ordinance so administered violated the Equal Protection Clause, the Court stated:

[T] he facts shown establish an administration directed so exclusively against a particular class of persons as to warrant and require the conclusion, that, whatever may have been the intent of the ordinances as adopted, they are applied by the public authorities charged with their administration, and thus representing the State itself, with a mind so unequal and oppressive as to amount to a practical denial by the State of that equal protection of the laws which is secured to the petitioners, as to all other persons, by the broad and benign provisions of the Fourteenth Amendment to the Constitution of the United States. Though the law itself be fair on its face and impartial in appearance, yet, if it is applied and administered by public authority with an evil eye and an unequal hand, so as practically to make unjust and illegal discrimination between persons in similar circumstances, material to their rights, the denial of equal justice is still within the prohibition of the Constitution.

The Court in Yick Wo made it clear that a statute constitutional on its face can be rendered unconstitutional upon a showing that the public officials charged with the administration of the statute discriminated against a distinct class of people in enforcing the statute.

${ }^{27} 118$ U.S. at 373-74. The Fourteenth Amendment provides in relevant part that "[n]o State shall ... deny to any person within its jurisdiction the equal protection of the laws." U.S. CONST. amend. XIV, $\$ 1$. Although there is no explicit corresponding prohibition on the federal government in the Constitution, the Supreme Court has interpreted the Due Process Clause of the Fifth Amendment as containing an "equal protection component" that subjects the federal government to the same equal protection standards as the Fourteenth Amendment does to the states. See Bolling v. Sharpe, 347 U.S. 497, 499 (1954) (subjecting racial segregation in the District of Columbia school system to the same constitutional standards applied in Browm v. Board of Education, 347 U.S. 483 (1954)); see also Weinberger v. Wiesenfeld, 420 U.S. 636, 638 n.2 (1975) ("This Court's approach to Fifth Amendment equal protection claims has always been precisely the same as to equal protection claims under the Fourteenth Amendment.").

\footnotetext{
${ }^{28}$ See Yick Wo, 118 U.S. at 368.

29 See id. at 374 .

so Id. at 373-74.
} 
Two key issues remained unresolved by the Yick Wo decision: (1) when such unconstitutional discrimination has occurred; that is, what classes of people are protected from unequal administration of the laws?; and (2) what proof is needed to demonstrate such unconstitutional discrimination?

\section{B. The Evolution of the Selective Prosecution Doctrine Since Yick Wo}

The Supreme Court addressed the first of these issues in Oyler $v$. Boles. $^{\text {s1 }}$ As in Yick Wo, the petitioner in Oyler alleged that a facially neutral recidivist statute was being selectively enforced against him in a manner that violated the Equal Protection Clause. ${ }^{32}$ Specifically, Oyler claimed that his selection for prosecution under the recidivist statute violated his equal protection rights. ${ }^{\text {ss }}$ Unlike $Y i c k$ Wo, however, the petitioner in Oyler did not claim that he was selected due to his affiliation with a certain class of people. He merely was complaining that he was selected for prosecution under the recidivist statute while others were not. In rejecting his equal protection argument, Justice Clark declared:

[T] he conscious exercise of some selectivity in enforcement is not in itself a federal constitutional violation. Even though the statistics in this case might imply a policy of selective enforcement, it was not stated that the selection was deliberately based upon an unjustifiable standard such as race, religion, or other arbitrary classification.

Together, Yick Wo and Oyler stand for the proposition that selective enforcement of a facially neutral statute based on unjustifiable standards, such as race, constitutes a violation of the Fourteenth Amendment's Equal Protection Clause. At the same time, these decisions recognize that some selectivity in enforcement of criminal laws is permissible and even necessary. These cases did not, however, address what evidence is required to prove such impermissible selective

368 U.S. 448 (1962).

32 In Oyler, the petitioner, having been previously convicted of three felonies punishable by imprisonment, was sentenced to life in prison pursuant to a West Virginia recidivist statute. See id. at 450 . The petitioner claimed that the state's application of the recidivist statute to his case amounted to unconstitutional selective prosecution. In support of his claim, he cited statistical data demonstrating that the recidivist statute's mandatory life sentence had been sought in his particular case but had not been sought by state prosecutors in 904 other cases in West Virginia in which it could have been sought. See id. at 455 .

ss See id.

${ }^{34} I d$. at 456 . 
prosecution-the second major issue left unresolved in Yick Wo. Both Yick Wo and Oyler seem to suggest that statistical evidence may suffice in certain situations to prove unconstitutional selective enforcement of a statute. ${ }^{35}$ This approach, nonetheless, is not the one taken by the Court since its decisions in Yick Wo and Oyler.

In Washington v. Davis, ${ }^{36}$ the Court held that in order for a facially neutral statute to violate the Equal Protection Clause, there must not only be discriminatory effects stemming from the application of the statute, but also a corresponding intent to discriminate. ${ }^{57}$ The Court reasoned:

The central purpose of the Equal Protection Clause of the Fourteenth Amendment is the prevention of official conduct discriminating on the basis of race. ... But our cases have not embraced the proposition that a law or other official act, without regard to whether it reflects a racially discriminatory purpose, is unconstitutional solely because it has a racially disproportionate impact.

Statistics of discriminatory enforcement of laws, seemingly sufficient to prove an equal protection violation in Yick Wo, were deemed necessary but not sufficient in Davis. ${ }^{39}$ Although not considered to-

${ }^{35}$ In fact, the Court's decision in Yick Wo seems to rest entirely on statistical evidence of selective enforcement of the municipal ordinance against Chinese laundry operators:

It appears that both petitioners have complied with every requisite, deemed by the law or by the public officers charged with its administration, necessary for the protection of ... the public health. No reason whatever, except the will of the supervisors, is assigned why they should not be permitted to carry on ... their harmless and useful occupation.... And while this consent of the supervisors is withheld from them and from two hundred others who have also petitioned, all of whom happen to be Chinese subjects, eighty others, not Chinese subjects, are permitted to carry on the same business under similar conditions. The fact of this discrimination is admitted. No reason for it is shown, and the conclusion cannot be resisted, that no reason for it exists except hostility to the race and nationality to which the petitioners belong, and which in the eye of the law is not justified.

Yick Wo, 118 U.S. at 374.

${ }^{36} 426$ U.S. 229 (1976).

${ }^{37}$ See id. at 239 . This case dealt with an equal protection challenge to a qualifying test given to applicants for police officer positions with the District of Columbia Metropolitan Police Department. The petitioners were black applicants who had failed the test and were claiming that the test violated the equal protection component of the Fifth Amendment. The applicants' claim was based on statistics that demonstrated that a higher percentage of black applicants failed the test than white applicants. No allegation was made that the test purposefully discriminated against black applicants. See id. at 235.

\footnotetext{
${ }^{38} I d$.

S9 See id. at 242.
} 
tally irrelevant in determining whether discriminatory purpose exists in a particular case, evidence of discriminatory effects was deemed "not the sole touchstone of ... invidious racial discrimination forbidden by the Constitution. ${ }^{n 0}$

In Wayte v. United States, the Court applied equal protection standards specifically to a claim of selective prosecution. The petitioner in Wayte had refused to register with the Selective Service System as required by federal law. ${ }^{42}$ The Government adopted an enforcement policy of prosecuting only those nonregistrants who were known to the Government, either because they notified the Government of their refusal to register or others had notified the Government. ${ }^{43}$ The petitioner was a vocal opponent of the Selective Service System $^{44}$ and, because the Government was therefore made aware of his failure to register, he was prosecuted. ${ }^{45} \mathrm{He}$ argued that the Government's enforcement policy violated the equal protection component of the Fifth Amendment. He alleged this violation because the policy selected for prosecution those offenders who had exercised their First Amendment rights by vocally stating their opposition to the Selective Service System, an acknowledged impermissible enforcement criterion. ${ }^{46}$

The Wayte Court noted that "[i]t is appropriate to judge selective prosecution claims according to ordinary equal protection standards. ... Under our prior cases, these standards require petitioner to show both ... a discriminatory effect and ... a discriminatory purpose. ${ }^{\not 77}$ Because the petitioner had only alleged discriminatory effects, his selective prosecution claim was rejected. ${ }^{48}$ Assuming there is no overt discriminatory classification present, therefore, the Court requires a defendant to inquire into a prosecutor's subjective motivations for her charging decisions in order to prove unconstitutional selective prosecution.

\footnotetext{
${ }^{40} I d$.

414 U.S. 598 (1985).

42 See id at 600-01.

13 See id. at 603.

44 See id. at 601 .

45 See id. at 603 .

46 See id. at 604-05.

47 Id. at 608.

48 See id. at 609 ("All petitioner has shown here is that those eventually prosecuted... reported themselves as having violated the law. He has not shown that the enforcement policy selected nonregistrants for prosecution on the basis of their
} speech."). 
The second major issue left unanswered by the Court in Yick Wonamely, what evidence is necessary in proving unconstitutional selective prosecution-was resolved in Wayte. The Court, by applying normal equal protection standards previously announced in Davis, ${ }^{49}$ required the defendant to prove that his selection for prosecution was based on purposeful, unjustifiable, discriminatory motives. Of course, proving subjective motivations is an extremely difficult task, and the question remained how a defendant could demonstrate purposeful discrimination beyond a mere statistical showing of discriminatory effects. ${ }^{50}$ In United States $v$. Armstrong, the defendant attempted to overcome this evidentiary obstacle in proving discriminatory racial motivation by seeking evidence from the U.S. Attorney's Office through discovery mechanisms. ${ }^{51}$

\section{United States v. Armstrong and the Discovery Debate}

Entitling a defendant to discovery that could lead to evidence of discriminatory motivation by a prosecutor in her decisionmaking process would be a useful tool for overcoming this evidentiary obstacle described in the previous section. In Wade $v$. United States, ${ }^{52}$ the Court indicated that a defendant must make a "substantial threshold showing" of improper prosecutorial motivations in order to be entitled to discovery or an evidentiary hearing on the issue of selective prosecution. ${ }^{53}$ The Court, however, did not indicate what level of evidence could meet this "substantial threshold showing" since Wade

${ }^{49}$ See supra notes $36-40$ and accompanying text.

${ }^{50}$ Members of the Court, as well as other federal judges, have recognized the difficulty of proving a person's subjective motivations in other contexts relating to discrimination, most notably in the context of employment discrimination. See Price Waterhouse v. Hopkins, 490 U.S. 228, 271 (1989) (O'Connor, J., concurring) (noting that the entire purpose of the shifting burdens of proof applicable in employment discrimination cases "is to compensate for the fact that direct evidence of intentional discrimination is hard to come by"); Sheridan v. E.I. DuPont de Nemours \& Co., 100 F.3d 1061, 1071 (3d Cir. 1996) ("The distinct method of proof in employment discrimination cases, relying on presumptions and shifting burdens of articulation and production, arose out of the Supreme Court's recognition that direct evidence of an employer's motivation will often be unavailable or difficuit to acquire.").

${ }_{51}$ See 116 S. Ct. 1480, 1483 (1996).

${ }^{52} 504$ U.S. 181 (1992). The petitioner in Wade argued that the prosecutor's refusal to file a motion to reduce petitioner's sentence due to his substantial assistance in the investigation of other cases violated equal protection standards. See id. at 183. The Court noted that a claim that a prosecutor failed to file a motion to reduce a defendant's sentence should be treated the same as any claim challenging the constitutional validity of a prosecutor's actions. See id. at 185.

${ }^{33}$ Id. at 186. 
had failed to allege any improper prosecutorial motives. ${ }^{54}$ The Armstrong case directly presented the issue of what constitutes a "substantial threshold showing" necessary for discovery, as Armstrong alleged the presence of discriminatory effects and motivation on the part of federal prosecutors. ${ }^{55}$

The Court in Armstrong reversed a discovery order that had been issued by the District Court for the Central District of California and affirmed by the Ninth Circuit en banc. This order would have compelled the district's U.S. Attorney's Office to disclose relevant information regarding Armstrong's claim of selective prosecution. ${ }^{56}$ Armstrong argued that the decision to prosecute his crack and firearm offenses in federal court, rather than in a California state court, was based on his race-a violation of the equal protection component of the Fifth Amendment. ${ }^{57}$ In support of this allegation, Armstrong presented statistical and anecdotal evidence that tended to demonstrate that while the defendants were black in an extremely disproportionate number of crack cases brought in federal courts, nonblacks were disproportionately being prosecuted in state court, and thus subject to less severe sentences. ${ }^{58}$ In denying the government's motion for reconsideration of her discovery order, Judge Marshall stated her reasons for granting discovery on Armstrong's selective prosecution claim, clearly believing the statistical evidence presented warranted a response from the U.S. Attorney:

${ }^{54}$ See id.

53 See Armstrong, 116 S. Ct. at 1483 (noting that the defendants had alleged "that they were selected for federal prosecution because they are black").

${ }_{56}$ Specifically, the district judge, Judge Marshall, had ordered the Government to:

(1) provide a list of all cases from the prior three years in which the government charged both cocaine base [crack] offenses and firearms offenses; (2) identify the race of the defendants in those cases; (3) identify whether state, federal, or joint law enforcement authorities investigated each case; and (4) explain the criteria used by the U.S. Attorney's Office for deciding whether to bring cocaine base cases to the federal court.

United States v. Armstrong, 48 F.3d 1508, 1511 (9th Cir. 1995). Judge Marshall's discovery order was reversed by a three-judge panel of the Ninth Circuit, see United States v. Armstrong, 21 F.3d 1431 (9th Cir. 1994), before being affirmed by the Ninth Circuit en banc, see 48 F.3d 1508 (9th Cir. 1995), and then reversed by the Supreme Court in an 8-1 decision with Justice Stevens dissenting, see 116 S. Ct. 1480 (1996).

${ }^{37}$ See Armstrong, 116 S. Ct. at 1483, 1486.

${ }^{58}$ See id. at 1483. Specifically, Armstrong presented evidence obtained from the Federal Public Defenders' Office that showed that of the 24 crack and firearm cases the Office had closed in 1991, all 24 defendants were black. Armstrong also presented anecdotal evidence in the form of an affidavit from a private criminal defense attorney that stated that, in his experience, many nonblacks were prosecuted for the same crack offenses in California state court rather than in federal court. See id. 
"The statistical data provided by the Defendant raises a question about the motivation of the Government which could be satisfied by the government disclosing its criteria ... for bringing this case and others like it in Federal court. Without this criteria the statistical data is evidence and does suggest that the decisions to prosecute in Federal court could be motivated by race. Without expert testimony, this Court cannot conclude that the defendants' evidence is explained by social phenomena [as the Government has suggested]. ${ }^{59}$

The Supreme Court, with Chief Justice Rehnquist writing for an eight-Justice majority, reversed Judge Marshall's discovery order. The Court held that the required threshold for discovery relating to a defendant's selective prosecution claim, alluded to in Wade, is "a credible showing of different treatment of similarly situated persons. ${ }^{n 00}$ The Court first rejected Armstrong's argument that Federal Rule of Criminal Procedure 16 entitled him to discovery, an argument that had not been made in the lower courts. ${ }^{61}$ Chief Justice Rehnquist then discussed the need to erect a "significant barrier to the litigation of insubstantial [selective prosecution] claims."

The Court found that the policy of affording prosecutors broad discretion in their decisionmaking processes justified the erection of the significant barrier. Although recognizing that prosecutorial dis-

${ }^{59}$ Amstrong, 48 F.3d at 1512 (quoting Judge Marshall's oral decision denying the Government's motion for reconsideration of her previous discovery order).

${ }^{60}$ Armstrong, $116 \mathrm{~S}$. Ct. at 1489 . Because Armstrong could not supply evidence demonstrating that similarly situated whites were treated differently than blacks by federal prosecutors based on their race, the Court held that Judge Marshall's discovery order was inappropriate. Responding to the Ninth Circuit's fear that, absent discovery, defendants face heavy evidentiary obstacles in proving possible meritorious selective prosecution claims, see 48 F.3d at 1514, the Court stated that, had Armstrong's selective prosecution claim been well founded, "it should not have been an insuperable task to prove that persons of other races were being treated differently than respondents." Armstrong, 116 S. Ct. at 1489.

${ }^{61}$ See Armstrong, $116 \mathrm{~S}$. Ct. at 1485. Federal Rule of Criminal Procedure $16(\mathrm{a})(1)(\mathrm{C})$ provides in pertinent part:

Upon request of the defendant the government shall permit the defendant to inspect and copy... books, papers, documents... or copies or portions thereof, which are within the possession, custody or control of the government, and which are material to the preparation of the defendant's defense or are intended for use by the government as evidence in chief at the trial ....

FED. R. CRIM. P. 16(a)(1)(C). The Court held this rule inapplicable to a defendant's claim of selective prosecution because such a claim is not a defense to the government's "case-in-chief." Armstrong, $116 \mathrm{~S}$. Ct. at 1485 . After rejecting this Rule 16 argument, the Court turned its attention to a district judge's inherent authority in ordering discovery beyond instances in which Rule 16 requires discovery.

${ }^{62}$ Armstrong, 116 S. Ct. at 1486. 
cretion is subject to constitutional constraints such as the equal protection component of the Fifth Amendment, ${ }^{63}$ the Court proceeded from a "presumption that a prosecutor has not violated equal protection [standards]."64 Judicial deference to prosecutorial discretion, the Court reasoned, is warranted by a number of factors, including: (1) avoiding unnecessary delay in criminal proceedings; (2) preventing the chilling of law enforcement that would occur if prosecutors' motives and decisionmaking were subject to outside inquiry by the courts on a regular basis; (3) preventing the undermining of prosecutorial effectiveness by revealing prosecutorial strategies; and (4) avoiding the encroachment by the judicial branch of government on the executive branch's constitutional function, namely the enforcement of the laws of the land. ${ }^{65}$

The Court's decision in Armstrong, by erecting what Chief Justice Rehnquist himself described as a "significant barrier" to proving selective prosecution claims, ${ }^{66}$ has effectively mooted an important constitutional protection recognized over one hundred years ago in Yick Wo. This "significant barrier," is a prototypical Catch-22: Equal protection is violated only when a prosecutor purposefully enforces a facially neutral statute against a person based on an impermissible factor such as race, but a defendant can only obtain evidence needed to prove such purposeful discrimination by establishing a substantial threshold showing of purposeful discrimination. In other words, a defendant can only prove that she was selected for prosecution in federal court rather than state court based on her race with evidence that will normally be in the possession of federal prosecutors. This evidence, however, is not discoverable because of the presumption of constitutional validity of discretionary prosecutorial decisionmaking. ${ }^{67}$

\footnotetext{
${ }^{63}$ See discussion infra Part II.B.1.

${ }^{64}$ Amsirong, 116 S. Ct. at 1486.

63 See id. For a more detailed examination of the commonly stated rationales for granting prosecutors broad discretion, see discussion infra Part II.A.

66 Armstrong, 116 S. Ct. at 1486.

67 This Catch-22 created by the Armstrong decision has been described by one source as "signal [ing] a disquieting insensitivity to the appearance of injustice." Leading Cases, supra note 23, at 170; see also David Cole, A Catch-22 Ruling on Selective Prosecution Law: A High Court Decision in an L.A. Appeal All but Guarantees that Racial Bias in Federal Crack Cocaine Cases Will Be Unprovable, L.A. TIMES, May 26, 1996, at M5 ("In effect, one must prove one's claim without access to the very evidence necessary to prove one's claim. Under this rule, the only time a selective prosecution claim might succeed would be if a U.S. [A]ttorney were to announce an official policy of targeting only blacks for prosecution. Beyond that, the defense of selective prosecution is a myth.").
} 
Moreover, the Court has created this Catch-22 at a time when the nation's war on drugs is apparently having a disproportionately punitive effect on black Americans, most notably in the area of crack prosecutions in federal court. ${ }^{68}$ Even if the disproportionate effects on black Americans have legitimate explanations, the refusal of federal prosecutors to provide evidence that would support such explanations leaves the perception of discrimination in the minds of many. ${ }^{69}$ This perception alone warrants the meaningful judicial review of prosecutorial discretion argued for in this Comment. If this meaningful review demonstrates that federal prosecutors are not injecting race into their decisionmaking processes, the concerns of

${ }^{68}$ These disproportionate punitive effects are demonstrated by the following statistics. It should be stressed that these statistics are not meant to indict federal prosecutors as being racially motivated. They merely demonstrate that the perceptions that racial bias exists in prosecutorial decisionmaking are grounded on the well-documented disproportionate impact of federal drug enforcement efforts relating to crack prosecutions. In the Central District of California (where the Armstrong case originated) between January 1992 and March 1995, only one federal crack defendant out of 149 was white. See United States v. Turner, 901 F. Supp. 1491, 1496 (C.D. Cal. 1995) (citing "a more recent and comprehensive prosecution study than was provided in [the Armstrong] case"). In a comprehensive study of both federal and state charging practices in Los Angeles, Richard Berk and Alec Campbell concluded that "African-Americans in general and African-Americans who are charged with offenses involving cocaine base in particular are at a greater risk of being charged with federal crimes than other... offenders." Richard Berk \& Alec Campbell, Preliminary Data on Race and Crack Charging Practices in Los Angeles, 6 FED. SENTENCING REP. 36, 38 (1993). This conclusion was based on the following data for individuals arrested for the sale of crack between 1990 and 1992: 222 crack defendants in state prosecutions were white compared to 4410 black defendants; meanwhile, not a single defendant in a federal crack prosecution was white, whereas 36 of the 43 crack defendants in federal court were black. See id. at 37. Because the total number of federal crack prosecutions is small, Berk and Campbell note that it is impossible to make strong conclusions on the basis of the available data- "[f]ar more information would be required." Id. at 38; see also Drew S. Days III, Race and the Federal Criminal Justice System: A Look at the Issue of Selective Prosecution, 48 ME. L. REV. 181, 186-87, 189 (1996) (listing additional statistics that demonstrate the disproportionate impact that crack prosecutions have on blacks and arguing that "serious and concerted efforts to locate explanations for nation-wide federal prosecution figures that appear, at a superficial level, to be out of line from a racial perspective" are necessary and ongoing).

69 See, e.g., Cole, supra note 67, at M5 ("There is little doubt that the black community is suspicious. ... The black community views the criminal justice system with deepseated and widespread distrust. That distrust has its roots in a long history of racial discrimination, but those roots are only replenished by decisions like Armstrong, which make it impossible even to ask the question whether a criminal prosecution was racially motivated."); David G. Savage, High Court Rejects Racial Challenge to L.A. 'Crack' Case, L.A. TIMES, May 14, 1996, at Al ("I would think in a democratic society, where there appears evidence of possible racial discrimination, we would want to get to the bottom of it' ...." (quoting George Kendall, a lawyer for the NAACP Legal Defense Fund)). 
those who believe federal prosecutors are acting in a discriminatory fashion would be alleviated. Equally significant, federal prosecutors themselves would be able to feel vindicated. ${ }^{70}$ The potential for constitutional abuse due to the increased federalization of criminal law requires a reexamination of the justifications for the broad grant of prosecutorial discretion that served as the basis for the Armstrong Court's mandate of judicial deference to prosecutorial decisionmaking.

\section{THE JUSTIFICATIONS FOR PROSECUTORIAL DISCRETION IN THE} CHARGING DECISION

As discussed in Part I.C, the Supreme Court's decision in Armstrong was based largely on the commonly stated justifications for allowing for broad prosecutorial discretion. ${ }^{71}$ Nowhere does this grant of broad prosecutorial discretion bestow any more power on prosecutors than in the decision whether to charge a person with a certain crime. One-time U.S. Attorney General Robert H. Jackson, who later became a Supreme Court Justice, described this awesome power and its potential for abuse in the following manner:

The prosecutor has more control over life, liberty, and reputation than any other person in America. His discretion is tremendous.... If the prosecutor is obliged to choose his cases, it follows that he can choose his defendants.... It is in this realm-in which the prosecutor picks some person whom he dislikes or desires to embarrass, or selects some group of unpopular persons and then looks for an offense, that the greatest danger of abuse of prosecutorial power lies. It is here that law enforcement becomes personal. ${ }^{72}$

${ }^{70}$ See Leading Cases, supra note 23, at 174 (listing several race-neutral factors that would explain the disproportionate statistics regarding federal drug prosecutions, but arguing that even if there are race-neutral reasons for the disparate treatment of blacks exemplified by these statistics, "both the public and the prosecutors' office would benefit from disclosure [like the district court ordered in Armstrong]").

7 See United States v. Armstrong, 116 S. Ct. 1480, 1486 (1996).

72 Robert H. Jackson, 24 J. AM. JUD. Soc. 18-19 (1940), quoted in DAVIS, supra note 22, at 190; see also Bordenkircher v. Hayes, 434 U.S. 357, 365 (1978) ("There is no doubt that the breadth of discretion that our country's legal system vests in prosecuting attorneys carries with it the potential for both individual and institutional abuse."); Charles P. Bubany \& Frank F. Skillern, Taming the Dragon: An Administrative Law for Prosecutorial Decisionmaking, 13 AM. CRIM. L. REV. 473, 476-78 (1976) (describing the prosecutor as "the single most powerful figure in the administration of criminal justice"). 
Yet courts are extremely reluctant to review prosecutorial discretion for the types of abuses alluded to by Attorney General Jackson. ${ }^{73}$ Instead, prosecutorial decisionmaking is cloaked with a presumption of validity, making a prosecutor's charging decision "essentially unreviewable." Given the increased potential for prosecutorial abuse stemming from the overlapping criminal jurisdiction of the state and federal courts, there is a need to reexamine a doctrine that leaves a federal prosecutor's charging decision virtually unchecked.

The commonly stated rationales for bestowing virtually unlimited discretion to prosecutors in making charging decisions, and the rationales cited by the Court in Armstrong, can be divided into four categories: (1) promoting prosecutorial and judicial economy and avoiding delay; (2) preventing the chilling of law enforcement; (3) avoiding the undermining of prosecutorial effectiveness; and (4) adhering to the constitutional principle of separation of powers and assessing the relative competence of the executive and judicial branches of government regarding the prosecutorial function. ${ }^{75}$ These justifications have led the Court to adopt the virtually irrebuttable presumption that a prosecutor is acting within constitutional limits. As long as there is "probable cause to believe that the accused committed an offense defined by statute, the decision whether or not to prosecute, and what charge to file or bring before a grand jury, generally rests entirely in his discretion. ${ }^{n 6}$ This discretion is cloaked in a

${ }^{73}$ Illustrative of this judicial reluctance to interfere with prosecutorial discretion despite the potential for abuse described by Attorney General Jackson is the fact that, before being reversed by the Supreme Court, the Ninth Circuit's decision in Armstrong was the first reported federal case since Yick Wo in which a court overturned a prosecutor's discretionary charging decision based on racial selective prosecution. See Leading Cases, supra note 23, at 171 .

${ }_{74}$ Vorenberg, supra note 22, at 1522; see also infra note 76 and accompanying text. Professor Vorenberg notes that while prosecutorial discretion remains broad, other actors' discretionary powers in the criminal justice system have been limited. He cites the limitations on the powers of magistrates to set bail, judges to set sentences, and correctional officers to control inmates. See Vorenberg, supra note 22, at 1522 . With the establishment of the Federal Sentencing Guidelines, federal judges retain even less discretion in sentencing than they did at the time Professor Vorenberg wrote, making the prosecutor's charging decision that much more important. See United States v. Williams, 746 F. Supp. 1076, 1082 (D. Utah 1990) ("Congress, through the minimum mandatory sentencing statutes and the sentencing guidelines, has severely curtailed the discretion of the court at sentencing, but no similar limitation has been placed on the exercise of discretion of police officers or prosecutors. This situation results in de facto sentencing by police and prosecutors."), rev'd in part, $963 \mathrm{~F} .2 \mathrm{~d} 1337$ (10th Cir. 1992) (affirming the conviction but remanding for sentencing).

\footnotetext{
${ }_{75}$ See supra text accompanying note 65 .

${ }^{76}$ Bordenkircher, 434 U.S. at 364.
} 
"'presumption of regularity [that] supports'... prosecutorial decisions and in the absence of clear evidence to the contrary, courts presume that [prosecutors] have properly discharged their official duties." 77 Moreover, Chief Justice Rehnquist's opinion in Armstrong established a self-described "significant barrier" to obtaining such clear and convincing evidence through discovery. ${ }^{78}$ Yet when the Court stated the aforementioned justifications for prosecutorial discretion, it merely listed them in a cursory fashion without inquiring into their merits. Prosecutorial discretion thus, is treated as gospel, resulting in a doctrine that prevails and prospers through inertia rather than through sound policy. ${ }^{79}$ Given the statistics regarding race and federal crack prosecutions, and more importantly the perceptions of racial bias that stem from these statistics, ${ }^{80}$ nowhere is a careful reexamination of the prosecutorial discretion doctrine more warranted than in the context of race-based selective prosecution claims.

The remainder of this Part will examine the four commonly stated rationales for prosecutorial discretion that served as the touchstone for the Court's decision in Armstrong. It will demonstrate that these rationales are unpersuasive in situations exemplified by $\mathrm{Am}$ strong, namely, when a person can be charged for the same offense in either state or federal court. The rationales, although admittedly based upon legitimate governmental interests, fail to justify the degree of discretion granted to prosecutors because they fail to balance

${ }^{77}$ Armstrong, 116 S. Ct. 1480, 1486 (1996) (quoting United States v. Chemical Found., Inc., 272 U.S. 1, 14-15 (1926)).

${ }^{78}$ Id. The Court felt that such a "significant barrier" was necessary to prevent "the litigation of insubstantial claims." Id. For a critique of this argument, see infra Part II.A.1.

${ }^{79}$ Professor Davis is especially critical of the inability of courts, and even many commentators, to question the soundness of bestowing upon our nation's prosecutors almost unlimited discretion:

[T] he habit of assuming that of course the prosecutor's discretion must be uncontrolled is so deeply embedded that the usual implied response to questions as to whether the prosecuting power can be confined or structured or checked is that the questioner must be totally without understanding. Inability of those who are responsible for administering the system to answer the most elementary questions as to the reasons behind the system is itself a reason to reexamine.

DAVIS, supra note 22 , at 191 . This need to reexamine the doctrine of prosecutorial discretion is even more pressing today with the increased potential for prosecutorial abuse that is caused by the trend toward increased federalization of criminal law. See supra notes $11-19$ and accompanying text.

${ }^{80}$ See supra notes 68-70. 
these legitimate interests against the important constitutional guarantee of equal protection of the laws.

\section{A. The Commonly Stated Rationales for Prosecutorial Discretion}

\section{Prosecutorial and Judicial Economy and the Avoidance of Delay}

\section{a. The Justification}

Prosecutorial and judicial economy are the most practical rationales for the broad grant of prosecutorial discretion discussed in Armstrong. Allowing frequent judicial review of prosecutors' charging decisions strains the limited resources of both the courts and prosecutors' offices in two ways. First, criminal statutes tend to define criminal conduct in broad terms. If prosecutors were compelled to proceed against a large percentage of offenders, prosecutorial and judicial resources would be strained even more so than they are today. ${ }^{81}$ Second, allowing judicial review of prosecutors' discretionary authority introduces the likelihood of collateral litigation that would further strain prosecutorial and judicial resources and cause lengthy delays in criminal proceedings. ${ }^{82}$ Given the already overwhelmed federal court docket, the argument goes, prosecutorial discretion is necessary to help curb the ever-increasing strain on the federal courts, especially the burgeoning criminal docket. ${ }^{83}$

81 See Steven Alan Reiss, Prosecutorial Intent in Constitutional Criminal Procedure, 135 U. PA. L. REV. 1365, 1368-69 n.10 (1987) (discussing the barriers to judicial review of the decision whether to prosecute); Vorenberg, supra note 22, at 1548 (summarizing the justification for prosecutorial discretion based on limited prosecutorial and judicial resources).

82 See Days, supra note 68, at 185 (arguing that close judicial scrutiny through discovery on selective prosecution claims is "extremely burdensome and timeconsuming"); Reiss, supra note 81, at 1368-69 n.10 ("Another defense is added. Another proceeding, a hearing to explore the defendant's allegations, is necessary.... Another clearly guilty defendant goes free." (citation omitted)); Developments in the Law-Race and the Criminal Process, 101 HARV. L. REV. 1472, 1523 (1988) [hereinafter Race and the Criminal Process] (stating that "practical concerns of efficiency militate against substantial judicial review of the prosecutorial charging decision").

${ }^{85}$ See Beale, supra note 11 , at 984,985 (noting that between 1980 and 1992 the number of criminal cases filed in federal courts increased by $70 \%$, from 27,968 to 47,472 , and stating that by 1992,38 of the 92 federal districts devoted over half of their trial dockets to criminal cases, with some district judges being unable to try a single civil case for a year or more). 


\section{b. The Response}

Preserving prosecutorial and judicial economy and avoiding delay in criminal proceedings are legitimate concerns when introducing any possible avenue for frivolous, collateral litigation, including a selective prosecution claim. There is a need, however, to account for these legitimate concerns without neglecting claims that are possibly meritorious. The Court in Armstrong seems to have ignored the possibility that a selective prosecution claim can be meritorious, despite the perceptions of racial bias in law enforcement generally, and the statistics that suggest race may be motivating federal prosecutorial decisionmaking specifically. ${ }^{84}$ By placing a "significant barrier" that must be overcome in order to prove selective prosecution, the Court has succumbed to "a fear of too much justice" in the name of prosecutorial and judicial economy. ${ }^{85}$

Any balance between the desire to avoid unnecessary strains on prosecutorial and judicial economy and the need to review governmental actions for possible abuses of discretionary power must consider not only the legitimate goal of preventing frivolous claims, but

${ }^{84}$ See supra notes $68-70$ and accompanying text. Moreover, race may be motivating prosecutorial decisionmaking for reasons other than conscious racism. Commentators have argued persuasively that racism is present both at a conscious and unconscious level:

Americans share a common historical and cultural heritage in which racism has played and still plays a dominant role. Because of this shared experience, we also inevitably share many ideas, attitudes, and beliefs that attach significance to an individual's race and induce negative feelings and opinions about nonwhites. To the extent that this cultural belief system has influenced all of us, we are all racists. At the same time, most of us are unaware of our racism.... In other words, a large part of the behavior that produces racial discrimination is influenced by unconscious racial motivation.

Charles R. Lawrence III, The Id, the Ego, and Equal Protection: Reckoning with Unconscious Racism, 39 STAN. L. REV. 317, 322 (1987) (footnote omitted); see also Race and the Criminal Process, supra note 82, at 1523 ("Given the vast extent of uncontrolled prosecutorial discretion, racial bias can enter the charging process in many ways. It can occur as the result of conscious prosecutorial policy. More significantly, discrimination can enter the charging decision in subtle or "unconscious' ways." (footnotes omitted)).

This unconscious racism is relevant in that it is the product of the very historical and cultural heritage that fuels the perceptions of racial bias in prosecutorial decisionmaking. Only if this decisionmaking is somehow made subject to public scrutiny can these perceptions be either verified or dispelled. Meaningful judicial review of prosecutorial discretion can supply this needed scrutiny. See discussion infra Part III.C.

${ }^{85}$ McCleskey v. Kemp, 481 U.S. 279, 339 (1987) (Brennan, J., dissenting); see also Leading Cases, supra note 23, at 175 (arguing that the Armstrong Court placed too much emphasis on the concern over flooding the courts with frivolous selective prosecution claims). 
also the importance of the constitutional right sought to be protected. The Court, in the same term as Armstrong, reiterated the paramount importance of the Constitution's guarantee of equal protection of the laws in another context. In Bush $v$. Vera, ${ }^{86}$ an equal protection challenge to alleged racial gerrymandering in electoral redistricting, the Court stated that "[i]f the promise of the Reconstruction Amendments, that our Nation is to be free of state-sponsored discrimination, is to be upheld, we cannot pick and choose ... in our efforts to eliminate unjustified racial stereotyping by government actors." ${ }^{87}$ Yet the Armstrong Court did "pick and choose" to insulate federal prosecutors from strict equal protection judicial scrutiny. As a result, any meaningful effort to inquire into the possibility that unjustified racial bias is being injected into the decision to charge was hampered. $^{88}$ The legitimate need for preserving limited prosecutorial and judicial resources should not compromise the "promise of the Reconstruction Amendments." Such a compromise seems to have been made by the Armstrong Court in holding that " $[t]$ he justifications for a rigorous standard for the elements of a selective-prosecution claim ... require a correspondingly rigorous standard for discovery in aid of such a claim. ${ }^{89}$

The argument that virtual unchecked prosecutorial discretion is warranted by the desire to conserve limited prosecutorial and judicial resources and to avoid delay in criminal proceedings is weakened in the context of the federal charging decision at issue in Armstrong. This is especially true when considering the perceptions of unconstitutional racial bias present in federal crack prosecutions. ${ }^{90}$ This is not to say that the availability to defendants of discovery regarding selective prosecution claims should be unfettered. A proper balance must be fashioned between the conservation of limited resources (as well as the other three rationales for a broad grant of prosecutorial discre-

\footnotetext{
${ }^{86} 116$ S. Ct. 1941 (1996).

${ }^{87}$ Id. at 1956.
}

${ }^{88}$ When I say that the Armstrong Court has insulated federal prosecutors from strict equal protection scrutiny, I do not mean that federal prosecutorial decisions based on race are not subject, at least in theory, to strict scrutiny. The insulation discussed does not stem from a different legal standard applicable to federal prosecutors, but rather from the extreme hardship the Court's decision in Armstrong confers upon criminal defendants trying to prove that race has entered the prosecutorial decisionmaking process. See supra notes $66-67$ and accompanying text (discussing the evidentiary Catch-22 created by the Armstrong decision).

${ }_{90}^{89}$ United States v. Armstrong, 116 S. Ct. 1480, 1488 (1996).

${ }^{90}$ See supra notes $68-70,84$ and accompanying text. 
tion $)^{91}$ and the protection of important constitutional rights by establishing a standard that allows facially meritorious selective prosecution claims to benefit from the discovery process.

\section{The Chilling of Law Enforcement}

\section{a. The Justification}

The Armstrong Court was also concerned with the chilling effect on law enforcement that might result from subjecting a prosecutor's motives to constant inquiry by the courts. ${ }^{92}$ The argument is that prosecutors may second-guess their charging decisions if they are constantly scrutinized by the courts. For example, a black crack defendant whose case should legitimately be brought in federal court ${ }^{93}$ might escape the more severe federal penalties because a prosecutor fears that a selective prosecution claim will subject her decision to careful judicial review through discovery and other judicial mechanisms. In a time when the efforts of the federal government are necessary in combating the crime situation in the United States, such a chilling of federal law enforcement is particularly troublesome. If indeed such a chilling effect would occur absent significant barriers to discovery on defendants' selective prosecution claims, then the extremely broad prosecutorial discretion bestowed upon prosecutors by the Armstrong Court would be justified.

\section{b. The Response}

There exists a legitimate concern that federal prosecutors will not zealously enforce federal drug laws due to the fear of substantial, collateral litigation resulting from selective prosecution claims. The sig-

${ }^{91}$ See discussion infra Part II.A.2-4.

92 See Armstrong, 116 S. Ct. at 1486 ("Examining the basis of a prosecution ... threatens to chill law enforcement by subjecting the prosecutor's motives and decisionmaking to outside inquiry ...." (quoting Wayte v. United States, 470 U.S. 598, 607 (1985))).

${ }^{93}$ Relevant to the selective prosecution issue discussed in this Comment, a prosecution is legitimately brought in federal court when the prosecutor's charging decision is not infected with considerations of the defendant's race. Former Solicitor General Drew S. Days III, whose office litigated the Armstrong appeal, alluded to several race-neutral factors that are relevant in crack prosecution charging decisions. These include: (1) the amount of drugs involved; (2) any firearm violations intertwined with the drug offense; (3) the strength of the overall evidence; (4) any threats made to law enforcement officers during the arrest; and (5) the past criminal history of the defendant. See Days, supra note 68, at 184. 
nificant barrier to proving selective prosecution created by the Court's Amstrong decision, however, strikes an inadequate balance between this concern and the constitutional guarantee of equal protection of the laws. If the purpose of the Equal Protection Clause "is the prevention of official conduct discriminating on the basis of race," ${ }^{, 94}$ mechanisms are needed so that citizens can determine, beyond a mere showing of disparate impact, when their constitutional rights have been violated. The reality of the situation is that only prosecutors possess information that would satisfy the discriminatory purpose prong of a selective prosecution claim, yet this evidence is undiscoverable according to Armstrong. ${ }^{95}$ The result is that defendants are left without a realistic opportunity to inquire into whether there exists "official conduct discriminating on the basis of race." The result is that the perceptions, if not the existence, of such discriminating official conduct are allowed to fester.

The Court has unnecessarily impeded the litigation of possible meritorious claims of serious constitutional violations due, in part, to a fear of the chilling effect that such claims might have on law enforcement. $^{96}$ If a crack prosecution legitimately belongs in federal court, a prosecutor need not fear unduly burdensome selective prosecution claims involving detailed discovery. ${ }^{97}$ In close cases, where the decision to proceed in federal court rather than state court is not an easy one, ${ }^{98}$ the threat of meaningful judicial review of the charging decision through discovery of the factors that were involved in the decisionmaking process is exactly the result desired if the constitutional prohibition of selective prosecution is to have any force. Secondguessing the charging decision in these close cases does not chill the

${ }^{94}$ Washington v. Davis, 426 U.S. 229, 239 (1976).

95 See supra note 50 (noting that the difficulty in obtaining evidence in an attempt to prove discriminatory purpose is precisely the reason why there are shifting burdens of proof in Title VII employment discrimination cases).

${ }^{96}$ See Armstrong, $116 \mathrm{~S}$. Ct. at 1486 (explaining that the high evidentiary burden "stems from a concern not to unnecessarily impair the performance of a core executive constitutional function").

${ }^{97}$ For a model standard for granting discovery that provides both a meaningful judicial check on prosecutorial discretion and a corresponding check on frivolous selective prosecution claims, see discussion infra Part III.

${ }^{98}$ The federal prosecutor, of course, does not literally decide if the state prosecutor's office will proceed with a prosecution. The decision to charge federally, however, is a de facto decision of whether to proceed in federal rather than state court. This is because a federal charge will likely foreclose the necessity of a state prosecution, whereas a decision not to charge federally will likely result in the initiation of state criminal proceedings by the local district attorney's office. 
zealous enforcement of federal criminal law; it protects against overzealous enforcement of these laws. ${ }^{\text {9 }}$ A careful review of the prosecutor's charging decision might disclose previously unrecognized racial factors that were injected into the initial charging decision. If the case then proceeds to federal court and a selective prosecution claim is made by the defendant, the added level of review by the court using discoverable evidence will further ensure that race is not part of the prosecutor's decisionmaking process.

In citing the need to prevent the chilling of law enforcement as a justification for the "significant barrier" placed before defendants seeking discovery on selective prosecution claims, the Court has once more struck an improper balance between a legitimate policy concern and a constitutional right. Protecting the zealous enforcement of federal criminal law, however, does not require unchecked prosecutorial discretion.

\section{The Undermining of Prosecutorial Effectiveness}

\section{a. The Justification}

A related concern expressed by proponents of broad judicial deference to prosecutorial decisionmaking is the fear that close judicial scrutiny of a prosecutor's decisions will reveal prosecutorial and law enforcement strategies, thus undermining effective crime control. ${ }^{100}$ This argument, in part, assumes that the uncertainty regarding who will be charged with federal (rather than state) crimes adds deterrent value over and above the deterrence stemming from the criminal prohibition itself. "Charging unpredictability can be seen, in this

${ }^{99}$ Cf. Allison Boyce, Case Note, Choosing the Forum: Prosecutorial Discretion and Walker v. State, 46 ARK. L. REv. 985, 999 (1994) (discussing a study that revealed that a number of prosecutors recognize that prosecutorial discretion brings with it the potential for "abuse by overzealous prosecutors seeking harsh punishments" (citing Donna M. Bishop \& Charles E. Frazier, Transfer of Juveniles to Criminal Court: $A$ Case Study and Analysis of Prosecutorial Waiver, 5 NOTRE DAME J.L. ETHICS \& PUB. POL'Y 281, $290(1991))$ ).

${ }^{100}$ See, e.g., Armstrong, 116 S. Ct. at 1486 ("'Examining the basis of a prosecution ... may undermine prosecutorial effectiveness by revealing the Government's enforcement policy." (quoting Wayte v. United States, 470 U.S. 598, 607 (1985))); Hollon, supra note 19, at 517 n.66 (stating that one objection to enhanced judicial scrutiny of prosecutors' charging decisions is that: "[P] rosecutors [have a] legitimate interest in shielding their use of charging discretion from public scrutiny. For example, where federal prosecutors are using threshold quantities of drugs as a basis for decisions to prosecute [federally], disclosure might problematically increase trafficking in amounts just under the threshold."). 
view, as a way of retaining some 'unearned' deterrence that would be lost if penalties were known and predictable." 101 Of course, this argument also assumes that criminals are rational actors who weigh all the costs and benefits of their contemplated criminal actions, a highly questionable and debated assumption. ${ }^{102}$ Notwithstanding the actual effectiveness of "unearned deterrence" programs such as Rudolph Giuliani's "federal day," some criminals will avoid the criminal justice system altogether if prosecutorial strategies are exposed through close judicial scrutiny of prosecutorial discretion. The interest in keeping these prosecutorial strategies from the public justifies broad prosecutorial discretion.

\section{b. The Response}

Providing for meaningful judicial review of prosecutorial discretion through discovery procedures need not undermine prosecutorial effectiveness. First, the "unearned deterrence"104 thought to be derived from the threat of more severe federal penalties for drug crimes is based on questionable assumptions and is undesirable even if such deterrence is obtainable. Second, any legitimate concerns over revealing prosecutorial strategies during discovery related to selective prosecution claims can be adequately addressed through judicial safeguards.

Any theory of deterrence assumes that criminals are rational actors that assess the costs and benefits of their contemplated criminal

${ }^{101}$ Vorenberg, supra note 22, at 1549-50. In other words, if one does not know whether one will be prosecuted on more severe federal charges, one is less likely to commit a crime in the first place. See id. at 1549-51 (explaining and critiquing the theory that charging uncertainty adds deterrent value to criminal laws).

${ }^{102}$ Compare Herbert L. PACKER, THE Limits OF THE Criminal SANCTION 41 (1968) (arguing that the "Benthamite" model of the criminal as a pure rational calculator is only partially accurate), with RICHARD A. POSNER, ECONOMIC ANALYSIS OF LAW 164-65 (2d ed. 1977) (arguing that the model of the criminal as a rational calculator, while apparently unrealistic, has substantial empirical support).

${ }^{103}$ Perhaps the best example of this "unearned deterrence" was former U.S. Attorney for the Southern District of New York, now Mayor of New York City, Rudolph Giuliani's policy of making one randomly chosen day of the week "federal day," in which all drug offenders arrested and charged that day were prosecuted in federal court. By keeping undisclosed what day of any week would be "federal day," Mr. Giuliani hoped that the threat of harsher federal sentences would deter drug crimes throughout the week by creating what he described as a "Russian-roulette effect." Beale, supra note 11, at 1000; see also William Glaberson, Giuliani's Pozverful Image Under Campaign Scrutiny, N.Y. TIMES, July 11, 1989, at Al (describing Mr. Giuliani's frequent references to his "federal day" policy during his later political campaigns for Mayor of New York City).

${ }^{104}$ See supra note 101 and accompanying text. 
acts before engaging in them. ${ }^{105}$ Accordingly, a potential criminal will assess the benefits from the contemplated criminal act and weigh them against the costs of the contemplated criminal act, which depend on the severity of the punishment and the likelihood of being caught. ${ }^{106}$ Uncertainty as to whether more severe federal charges will be pursued, the argument goes, generates increased deterrence. ${ }^{107}$ This argument is of questionable validity and empirical studies demonstrate that, at the least, the evidence is inconclusive as to whether the severity of punishment deters criminal behavior. ${ }^{103}$ Until better evidence can be obtained that supports the theory that the threat of stiffer federal sentences deters crimes in general, and drug crimes in particular, this argument cannot justify unchecked prosecutorial discretion with its concomitant potential for constitutional violations.

Professor James Vorenberg criticizes this alleged deterrence rationale for prosecutorial discretion on another empirical ground. Uncertainty as to whether one will be prosecuted, Professor Vorenberg argues, may lead criminals, "many [of whom] are risk takers by nature, ... to underestimate the risk once they acquire a general impression of uneven enforcement. ${ }^{109}$ Although Professor Vorenberg was writing in the context of a decision whether to prosecute at all, this argument is equally relevant to the decision whether to seek

${ }^{103}$ See POSNER, supra note 102, at 163-64 ("The function of the criminal law, viewed from an economic standpoint, is to impose additional costs on unlawful conduct where the conventional damages remedy alone would be insufficient to limit that conduct to the efficient level."); Gary S. Becker, Crime and Punishment: An Economic Approach $76 \mathrm{~J}$. POL. ECON. 169, 207-09 (1968) (arguing that the frequency of criminal activity can be reduced by increasing the costs imposed on the activity).

${ }^{106}$ See POSNER, supra note 102 , at 165 ("The product of probability and severity is the cost of crime to the risk-neutral offender.").

${ }^{107}$ See supra note 101 and accompanying text.

109 See, e.g., PACKER, supra note 102, at 41; Raymond Paternoster et al., Perceived Risk and Social Control: Do Sanctions Really Deter?, I7 LAW \& Soc. REV. 457, 457 (1983) ("[T] he preliminary evidence suggests that the perceived risk of punishment has a deterrent effect, while the perceived severity of punishment does not."); Andrew von Hirsch, Recent Trends in American Criminal Sentencing Theory, 42 MD. L. REV. 6, 19 (1983) (arguing that the failure of empirical studies to control for other factors that affect the crime rate besides the severity of punishment demonstrates that "[a]lthough there is reason to believe that some penalty deters better than none, researchers are still unable reliably to measure the magnitude of deterrent effects [from increased penalties]").

${ }^{09}$ Vorenberg, supra note 22, at 1550. But see RICHARD A. POSNER, ECONOMIC ANALYSIS OF LAW 230 (4th ed. 1992) (considering the economic efficiency of subjecting a minority of offenders with a lower probability of apprehension and conviction to harsher sentences, while subjecting the majority to less severe sentences for similar conduct), cited in Beale, supra note 11, at 1003 n.104. 
stiffer federal sanctions or less severe state sentences. In other words, the knowledge that less severe state sanctions might be sought against her if caught will lead to a criminal's decision to proceed with her unlawful plan, thus decreasing the deterrent effects thought to be derived from more severe federal sentences.

In addition to the questionable empirical validity of this unearned deterrence theory, one must consider the inherent unfairness present when criminal laws are enforced arbitrarily. The disparate sentencing structures of the federal and state penal systems, especially in the area of illegal drugs, coupled with the concurrent jurisdiction of criminal law, create what one commentator has described as a "cruel lottery, in which a small minority of the persons who commit a particular offense is selected for federal prosecution and subjected to much harsher sentences... than persons prosecuted for parallel state offenses." 110 Moreover, even absent any racial bias in the functioning of this "cruel lottery" (an assumption that is certainly not supported by the many who perceive such bias given available statistics), ${ }^{111}$ arbitrary selection of certain offenders for federal prosecution is at odds with the policy of evenhanded sentencing embodied in the Federal Sentencing Guidelines. ${ }^{12}$

Undermining the full deterrent effect of criminal law, however, is not the only perceived threat to effective law enforcement that is thought to justify unlimited prosecutorial discretion. Knowledge of federal prosecutorial strategies may result in criminals structuring their crimes to ensure state prosecutions and thus, less severe sentences against them if caught. ${ }^{113}$ This argument does not justify such broad prosecutorial discretion for two reasons: (1) even if criminals do structure their crimes in such ways, this is not necessarily undesirable; and (2) judicial safeguards are available that can prevent disclosure of law enforcement strategies that would harm criminal enforcement efforts.

First, advance knowledge of certain federal prosecutorial strategies, such as the factors used to determine when a crime will be prosecuted federally, may actually be a useful deterrent tool-perhaps

${ }^{110}$ Beale, supra note 11 , at 997.

11 See supra notes 68-70 and accompanying text.

112 See Beale, supra note 11, at 1003-04 (arguing that arbitrary selection of a minority of offenders for federal prosecution "is incompatible with the federal Sentencing Guidelines regime" that is "devoted... to equalizing the sentences for offenders whose conduct and criminal history are the same").

${ }^{113}$ See supra note 100. 
more useful than the "unearned deterrence" from unguided, uneven enforcement policies such as Rudolph Giuliani's "federal day." " For example, if it is widely known that committing a drug crime with a firearm is a factor that will lead to federal prosecution, ${ }^{115}$ a drug offender may be deterred from using a firearm. Although the drug crime is still committed, it has been committed in a more benign manner. Such deterrence, although incomplete, is certainly a potentially valuable tool for law enforcement.

Second, judicial safeguards can be utilized when law enforcement strategies must be kept relatively confidential in order to ensure safe, effective crime control. There can be no argument that general knowledge of certain prosecutorial policies may indeed undermine law enforcement efforts. ${ }^{116}$ To the extent that such information is necessary for meaningful judicial review of prosecutorial discretion in the selective prosecution context, mechanisms can be utilized to ensure that law enforcement effectiveness is not compromised, such as in camera review of relevant evidence and protective orders. ${ }^{117}$ Such mechanisms are used in other analogous contexts to balance the need for review of relevant evidence with the need for secrecy. ${ }^{118}$

A careful examination of the fear of undermining the effectiveness of law enforcement through discovery on selective prosecution claims reveals that virtually unchecked prosecutorial discretion represents an inadequate balance between competing policies. First, the

${ }^{114}$ See Vorenberg, supra note 22, at 1550 ("[G]uidelines that provide advance knowledge that committing a crime in as benign a way as possible results in relatively lenient treatment may be valuable.").

${ }^{115}$ See supra note 93 (noting that use of a firearm during the commission of a drug crime is a factor that is considered when deciding to prosecute a case federally).

${ }^{116}$ A good example of such policies are the actual crime fighting strategies of federal law enforcement officers. Knowledge of how and where federal law enforcement agents investigate drug activity may be highly relevant in determining whether race is entering into the decision to proceed federally with a case. Yet, advance knowledge of such strategies not only undermines law enforcement effectiveness but endangers the lives of law enforcement agents by potentially forewarning criminals of law enforcement activity.

117 See Hollon, supra note 19, at 517 n.66 (arguing that in camera review of sensitive prosecutorial material "would allow judges to address egregious misuses of charging discretion while protecting prosecutors' interests in nondisclosure").

${ }^{118}$ See, e.g., FED. R. CIV. P. 26(c) (providing for protective orders when necessary "to protect a party or person from annoyance, embarrassment, oppression, or undue burden or expense," due to discovery requests); see also infra notes 157-58 (noting that the risk of revelation of trade secrets is a factor a court may consider in balancing a corporation's right to assert the attorney-client privilege against the shareholders' rights to discovery). 
empirical evidence of added deterrence from broad prosecutorial discretion is simply too weak to support a policy that injects into the criminal justice system an avenue for misuse of governmental powers as severe as a denial of equal protection of the laws. Second, as with the rationales for prosecutorial discretion discussed above in Parts II.A.1 \& 2, the Court's "significant barrier" to discovery on selective prosecution claims is not necessary to prevent the undermining of law enforcement effectiveness. A more generous discovery standard, one that not only takes into account the rationales for prosecutorial discretion, but also balances the need to protect defendants' constitutional rights, is necessary and readily obtainable.

\section{Separation of Powers and the Relative Competence of the Executive and Judicial Branches Regarding the Prosecutorial Function}

\section{a. The Justification}

Perhaps the most often espoused rationale for the broad grant of unchecked discretionary authority granted to American prosecutors (both state and federal) is based on the constitutional principle of separation of powers among the three branches of government. "The separation of powers doctrine generally prevents judicial interference with a prosecutor's broad discretion to initiate and conduct criminal prosecutions." tion of powers justification for prosecutorial discretion in the broadest terms when it wrote:

Few subjects are less adapted to judicial review than the exercise by the Executive of his discretion in deciding when and whether to institute criminal proceedings....

... Two persons may have committed what is precisely the same legal offense but the prosecutor is not compelled by law, duty or tradition to treat them the same.... [N]o court has any jurisdiction to inquire into or review his decision.

... [W] hile this discretion is subject to abuse ... deviations from his duty as an agent of the Executive are to be dealt with by his superiors.

${ }^{119}$ James Sottile IV, Prosecutorial Discretion, 73 GEO. L.J. 403, 403 (1984). 
... [I]t is not the function of the judiciary to review the exercise of executive discretion whether it be that of the President himself or those to whom he has delegated certain of his powers.

In addition to the argument that the judiciary cannot constitutionally interfere with the proper role of the Executive Branch, many courts and commentators, including the Armstrong Court, view prosecutors as relatively more competent than courts in making such decisions as whom to bring charges against and where to bring these charges. This is due to the fact that it is prosecutors who confront these types of issues on a daily basis. ${ }^{121}$

\section{b. The Response}

The Constitution vests in the President the duty to "take Care that the Laws be faithfully executed, ${ }^{122}$ and Congress has delegated part of this duty, the power to enforce federal criminal laws, to the Attorney General and United States Attorneys. ${ }^{123}$ It is, therefore, the province of the Executive Branch of government, acting through the President, the Attorney General, and most directly, each judicial district's United States Attorney's Office, to enforce federal criminal law. Because the Executive Branch functions in this prosecutorial role on a daily basis, executive officers are most competent in making the everyday decisions necessary in enforcing federal criminal law, such as whom to prosecute. ${ }^{124}$ This fact however, does not support the level of prosecutorial discretion endorsed by the Armstrong Court.

${ }^{120}$ Newman v. United States, 382 F.2d 479, 480-82 (D.C. Cir. 1967); see also United States v. Armstrong, 116 S. Ct. 1480, 1486 (1996) (explaining that federal prosecutors have broad discretion to enforce federal criminal law "because they are designated by statute as the President's delegates to help him discharge his constitutional responsibility to "take Care that the Laws be faithfully executed" (quoting U.S. CONST. art. II, §3)). But see United States v. Batchelder, 442 U.S. 114, 125 (1979) (holding that a prosecutor's discretion is "subject to constitutional restraints" enforceable by the courts).

${ }^{121}$ See, e.g., Armstrong, $116 \mathrm{~S}$. Ct. at 1486 ("Judicial deference to the decisions of [federal prosecutors] rests in part on an assessment of the relative competence of prosecutors and courts."); Wayte v. United States, 470 U.S. 598, 607 (1985) (describing common factors considered in making charging decisions as "not readily susceptible to the kind of analysis the courts are competent to undertake"); Reiss, supra note 81, at 1368-69 n.10 (describing the prosecutor-as-expert argument for judicial deference to prosecutorial discretion). But see Vorenberg, supra note 22, at 1545-48 (describing and criticizing this expertise argument for unfettered prosecutorial discretion).

122 U.S. CONST. art. II, § 3.

${ }^{123}$ See 28 U.S.C. $\$ \S 516,547$ (1994).

${ }^{124}$ See supra note 120 and accompanying text. 
In supporting its view that federal prosecutors "retain 'broad discretion' to enforce the Nation's criminal laws," the Armstrong Court was clearly concerned with infringing upon the "special province" of the Executive Branch of government. ${ }^{125}$ This separation of powers argument is a long-standing justification for such broad prosecutorial discretion and was described by the Fifth Circuit in 1965 as mandating that "the courts are not to interfere with the free exercise of the discretionary powers of the attorneys of the United States in their control over criminal prosecutions. ${ }^{126}$ To cloak prosecutorial discretionary decisionmaking in a presumption of regularity based on the fact that enforcement of the nation's criminal laws is the "special province" of the Executive Branch, however, ignores the proper role of the judicial branch within the constitutional system of checks and balances.

Professor Kenneth Culp Davis criticizes the separation of powers argument for prosecutorial discretion in similar, if not more powerful, terms:

This reason [for unchecked prosecutorial discretion] is so clearly unsound as to be almost absurd. If separation of powers prevents review of discretion of executive officers, then more than a hundred Supreme Court decisions spread over a century and three-quarters will have to be found contrary to the Constitution! If courts could not interfere with abuse of discretion by executive officers, our fundamental institutions would be altogether different from what they are. If the statement just quoted from the Fifth Circuit [in United States v. Cox] were true, the courts would be powerless to interfere when executive officers, acting illegally, are about to execute an innocent person! ${ }^{127}$

Because one of the functions of the courts is to review executive discretionary actions for abuse of that discretion, the rationale for a

${ }^{125}$ Armstrong, $116 \mathrm{~S}$. Ct. at 1486 ("A selective-prosecution claim asks a court to exercise judicial power over a 'special province' of the Executive. The Attorney General and the United States Attorneys retain 'broad discretion' to enforce the Nation's criminal laws. They have this latitude because they are designated by statute as the President's delegates to help him discharge his constitutional responsibility [to enforce the nation's laws]." (citations omitted)).

${ }_{126}$ United States v. Cox, 342 F.2d 167, 171 (5th Cir. 1965).

${ }^{127}$ DAVIS, supra note 22, at 210 . For an example of judicial review of executive actions for abuse of discretion, one need look no further than Yick Wo v. Hopkins, 118 U.S. 356, 373-74 (1886), the case that established the constitutional protection against selective prosecution. See discussion supra Part I.A. For a full presentation of the case law alluded to by Professor Davis in the above quotation see KENNETH CULP DAVIS, 5 ADMINISTRATIVE LAW TREATISE $§ \$ 28: 1-15$ (2d ed. 1984). 
"significant barrier" to discovery in selective prosecution claims based on a separation of powers argument is unpersuasive.

More persuasive is the argument that prosecutors should be granted broad discretion in their decisionmaking processes due to their relative competence compared to the courts in making decisions such as whom and where to prosecute. ${ }^{128}$ This argument, however valid it might be when a court is asked to review a prosecutor's assessment of "the prosecution's general deterrence value, the Government's enforcement priorities, and the case's relationship to the Government's overall enforcement plan," ${ }^{129}$ loses its validity when a court is asked to review prosecutorial actions for constitutional violations, a task courts are called upon to do on a regular basis. The Armstrong Court, by embracing a valid justification for the doctrine of prosecutorial discretion in other contexts, without assessing its validity in the selective prosecution context, has seriously undermined the constitutional guarantee of equal protection.

\section{B. Affirmative Responses to the Justifications for Prosecutorial Discretion}

\section{The Unequivocal Constitutional Mandate of Equal Protection}

The traditional rationales for granting prosecutors broad discretionary powers do not justify unchecked prosecutorial discretion in the context of the decision to prosecute federally. In large measure this is due to their failure to balance adequately competing constitutional interests. Perhaps the most persuasive reason for meaningful judicial review of such prosecutorial discretion was alluded to by the Court in Armstrong, although the Court did not follow the argument to its logical conclusion. After determining that the traditional justifications for broad prosecutorial discretion insulate a prosecutor's charging decision from judicial review "so long as the prosecutor has probable cause to believe that the accused committed an offense defined by statute," ${ }^{130}$ the Court acknowledged that "[o]f course, a prosecutor's discretion is 'subject to constitutional constraints."”131

${ }^{128}$ See Wayte v. United States, 470 U.S. 598, 607 (1985) (arguing that broad prosecutorial discretion is necessary because the decision whether to prosecute is "particularly ill-suited to judicial review").

${ }_{129} I d$.

190 Armstrong, 116 S. Ct. at 1486 (quoting Bordenkircher v. Hayes, 434 U.S. 357, 364 (1978)).

${ }^{191}$ Id. (quoting United States v. Batchelder, 442 U.S. 114, 125 (1979)). 
The Court then proceeded to set its self-described "significant barrier" for defendants seeking to obtain discovery on their equal protection claims, thus subjecting prosecutorial discretion to virtually no constitutional constraints. ${ }^{132}$ This "significant barrier" was deemed by the Court to "adequately balance[] the Government's interests in vigorous prosecution and the defendant's interest in avoiding selective prosecution." ${ }^{\text {133 }}$ Balancing practical governmental interests, such as an interest in vigorous prosecution, with a defendant's constitutional rights, however, has been deemed inappropriate by the Supreme Court in other contexts. In Payton v. New York, ${ }^{134}$ the Court, determined that the Fourth Amendment prohibits the police from entering a suspect's home to arrest him without first obtaining a warrant. The Court rejected the government's contention that such a warrant requirement would undermine effective law enforcement. ${ }^{135}$ In addition to questioning the validity of the government's asserted policy interests, the Court stated: "More fundamentally, however, such arguments of policy must give way to a constitutional command that we consider to be unequivocal." constitutional command of equal protection of the laws should not be unduly burdened by the policy interests that served as the justification for a "substantial barrier" to selective prosecution claims in Armstrong. ${ }^{137}$

\section{Necessity}

The Armstrong Court set a high threshold for discovery partly under an assumption that if Armstrong's "claim of selective prosecution were well founded, it should not have been an insuperable task to prove that persons of other races were being treated differently than

${ }^{132}$ See id. at 1488 (noting that a selective prosecution claim requires a "rigorous standard for discovery").

${ }^{133}$ Id. at 1489 .

154445 U.S. 573 (1980).

${ }^{135}$ The State of New York had argued that such a warrant requirement would have a number of negative practical consequences:

[It] will pressure police to seek warrants and make arrests too hurriedly, thus increasing the likelihood of arresting innocent people; ... it will divert scarce resources thereby interfering with the police's ability to do thorough investigations; ... it will penalize the police for deliberate planning; and ... it will lead to more injuries.

Id. at 602 n.55.

${ }^{196} I d$. at 602.

137 See discussion supra Part II.A. 
[he]. ${ }^{.138}$ This statement, however, is of questionable merit. As the Ninth Circuit expressed in affirming the district court's discovery order:

[J]udges considering discovery requests on selective prosecution charges should bear in mind the evidentiary obstacles defendants face. The notorious difficulty of proving a race discrimination claim is particularly acute in the context of selective prosecution claims.... The broad discretion that prosecutors possess over charging decisions means that they alone will often possess the only information that would demonstrate such discrimination.... As a result, the data necessary to a showing of selective prosecution are far less accessible to the defendants than to the government. ${ }^{139}$

The significant barrier to discovery on selective prosecution claims, given the evidentiary obstacles inherent in any attempt to prove subjective racial motivation, effectively bars the litigation of selective prosecution claims on the merits. The result is that the government's interests in maintaining broad discretion in prosecutorial decisionmaking is not at all balanced with a defendant's interest in avoiding unconstitutional selective prosecution.

Instead, under the Armstrong Court's high threshold of evidence necessary merely to obtain discovery on a selective prosecution claim, the government's interests, some of which are admittedly legitimate, ${ }^{140}$ invariably predominate over a defendant's interest in avoiding selective prosecution.

\section{Summary}

The Armstrong Court erred in two significant ways by setting a high threshold of evidence necessary for a defendant to obtain dis-

199 Armstrong, 116 S. Ct. at 1489 . To prove that other races were treated differently, the Court gave an example of the type of evidence that respondents could have easily obtained. See id. ("For instance, respondents could have investigated whether similarly situated persons of other races were prosecuted by the State of California, were known to federal law enforcement officers, but were not prosecuted in federal court."). The Court does not, however, explain how a defendant is to prove federal law enforcement officers knew of a criminal violation but did not pursue the case in federal court without some level of discovery.

${ }^{139}$ United States v. Armstrong, 48 F.3d 1508, 1514 (9th Cir. 1995) (citing Wayte v. United States, 470 U.S. 598, 624 (1985) (Marshall, J., dissenting)). Illustrative of the Ninth Circuit's argument, before being reversed by the Supreme Court, the Ninth Circuit's decision in Armstrongwas the first reported federal case since Yick Wo in which a defendant succeeded on her claim of racial selective prosecution. See Leading Cases, supra note 23 , at 171 .

${ }^{140}$ See discussion supra Part II.A. 
covery on a selective prosecution claim based on the common rationales for prosecutorial discretion. First, the Court treated the traditional rationales for broad prosecutorial discretion as gospel without carefully examining and balancing the policies underlying these rationales with countervailing interests, namely a defendant's right to equal protection of the laws. ${ }^{141}$ Second, even after a cursory acknowledgment of the important constitutional right at stake, the Court failed to consider whether balancing the constitutional mandate of being free from selective prosecution with practical policy considerations is even appropriate in the first place. This failure is especially relevant given the unequivocal nature of that mandate and the necessity of making discovery of prosecutorial material available to criminal defendants in order to effectuate the purposes of that mandate. ${ }^{142}$ There is a need, therefore, for judicial reevaluation of the basic premises that served as the foundation for the Court's decision in Armstrong, and a need for a model that will supply meaningful judicial review of prosecutorial discretion.

\section{The PROSECUTOR AS FidUCIARY: A MODEL FOR MEANINGFUL REVIEW OF PROSECUTORIAL DISCRETION ${ }^{143}$}

Seeking a working model for meaningful review of prosecutorial discretion requires an examination of analogous situations where litigants seek discovery of otherwise unobtainable evidence. Cases where beneficiaries of fiduciary relationships request otherwise privileged information from the fiduciary provide such an analogy. ${ }^{144}$ This situation arises frequently, although certainly not exclusively, in the context of corporate derivative suits where shareholders sue the directors and officers of a corporation for mismanagement in the name of the

141 See id.

142 See discussion supra Part II.B.

143 The model for meaningful judicial review of prosecutorial discretion presented in this Part was inspired by a discussion of to whom lawyers owe duties when confronted with a client who owes fiduciary duties to a third party. See GEOFFrEY C. HAZARD, JR., ET AL., THE LAW AND ETHICS OF LAWYERING 808 (2d ed. 1994) (questioning whether "individuals who allege the government has violated its trust [should be entitled] to discover communications of government lawyers upon a showing of good cause").

${ }^{144}$ See, e.g., FED. R. CIV. P. 30-36 (detailing available discovery mechanisms for civil litigation in federal court); see also FED. R. CIV. P. 26(b) (1) ("Parties may obtain discovery regarding any matter, not privileged, which is relevant ...."). 
corporation. ${ }^{145}$ In this context, shareholders seek discovery of relevant information pertaining to their underlying claim of corporate mismanagement. ${ }^{146}$ Normally, this information .would be immune from discovery due to the attorney-client privilege because it consists of communications between corporate officials and corporate attorneys that relate to the latter's representation of the former. ${ }^{147}$

In the landmark case of Garner $v$. Wolfinbarger, ${ }^{148}$ however, the Fifth Circuit fashioned an exception to the corporate attorney-client privilege, by allowing for discovery of otherwise privileged evidence in certain situations. ${ }^{149}$ The final Part of this Comment first examines the rationale of the Garner exception to the attorney-client privilege, and demonstrates that it is based on the fiduciary relationship between corporate management and shareholders. Next, by arguing that a prosecutor has a similar fiduciary relationship with a defendant in a criminal case, this Comment draws an analogy between a claim of corporate mismanagement and a claim of prosecutorial misuse of discretion resulting in unconstitutional selective prosecution. Finally,

145 In addition to the shareholder derivative suit, other notable situations where such discovery is sought include union members suing their national unions, see, e.g., Nellis v. Airline Pilots Ass'n, 144 F.R.D. 68 (E.D. Va. 1992), and insureds suing their insurance companies, see e.g., A. Kush \& Assocs. v. Wein Geroff Enter., Inc., No. 85C493, 1986 WL 15120, at *2 (N.D. Ill. Dec. 31, 1986). See generally Robert R. Summerhays, The Problematic Expansion of the Garner v. Wolfinbarger Exception to the Corporate Attorng-Client Privilege, 31 TULSA L.J. 275, 308-12 \& nn.167-91 (1995) (discussing various litigation situations where parties attempt to obtain discovery of otherwise privileged information other than in corporate derivative litigation).

${ }^{145}$ See, e.g., Sandberg v. Virginia Bankshares, Inc., 979 F.2d 332, 341 (4th Cir. 1992) (shareholders seeking attorney-client communications related to a corporate merger); In Re International Sys. \& Controls Corp. Sec. Litig., 693 F.2d 1235, 1238 (5th Cir. 1982) (shareholders seeking attorney-client communications related to alleged securities law violations); Garner v. Wolfinbarger, 430 F.2d 1093, 1095 (5th Cir. 1970) (shareholders seeking attorney-client communications related to an alleged fraudulent issuance of stock).

${ }^{147}$ See 8 JOHN HENRY WIGMORE, EVIDENCE IN TRIALS AT COMMON LAW $\$ 2292$, at 554 (rev. 1961). Wigmore defines the requirements of the attorney-client privilege as:

(1) Where legal advice of any kind is sought (2) from a professional legal advisor in his capacity as such, (3) the communication relating to that purpose, (4) made in confidence (5) by the client, (6) are at his instance permanently protected (7) from disclosure by himself or by the legal adviser, (8) except the protection be waived.

Id. (emphasis omitted).

148430 F.2d 1093 (5th Cir. 1970).

149 Almost all federal courts have adopted the Gamer exception to the corporate attorney-client privilege. See Summerhays, supra note 145, at $287 \&$ n. 49 (noting that the only reported federal case failing to adopt the Gamer exception is Shirvani v. Capital Investing Corp., 112 F.R.D. 389, 391 (D. Conn. 1986)). 
this Part presents a model for providing meaningful judicial review of prosecutorial discretion, drawing its essence from the Gamer exception to the corporate attorney-client privilege.

\section{A. Garner v. Wolfinbarger and Discovery of Otherwise Privileged Information from a Fiduciary}

The plaintiff-shareholders in Garner brought a shareholder class action lawsuit and a derivative suit alleging that corporate management violated several federal and state laws related to the issuance of corporate stock. ${ }^{150}$ The plaintiff-shareholders alleged that, as purchasers of the stock, the defendants' actions caused personal injury to them, as well as injury to the corporation itself. ${ }^{151}$ In their effort to gather evidence in support of their allegations, the shareholders sought information, both in the form of oral testimony and documentary evidence, regarding legal advice that corporate counsel had given related to the issuance of corporate stock. The corporate counsel, who at the time of the litigation had become the corporation's president, refused to comply with these discovery requests, asserting that they were protected by the attorney-client privilege. The district court ordered discovery, holding that corporate management could not assert the attorney-client privilege to bar discovery of evidence relating to the shareholders' claims of corporate mismanagement. The corporation had argued that the attorney-client privilege is absolute and protects communications between an attorney and a corporate client that relate to the particular representation, regardless of the status of the plaintiffs in a lawsuit. ${ }^{152}$

The Fifth Circuit rejected these extreme positions, instead recognizing "the need for balancing competing interests in disclosure and nondisclosure. ${ }^{n 53}$ The court acknowledged the legitimate interests corporate management has in maintaining the confidentiality of attorney-client communications. ${ }^{154}$ The court, however, also recognized

${ }^{150}$ The shareholders alleged violations of the Securities Act of 1933, 15 U.S.C. \$77a-77aa, the Securities and Exchange Act of 1934, 15 U.S.C. $\$ 78 \mathrm{a}-78 \mathrm{hh}-1$, the Investment Advisors Act of 1940,15 U.S.C. $\S 80 a-1-80 a-52$, the Alabama Securities Act, 53 AlA. CODE § 28-65 (1969 Supp.), and common law fraud. See Gamer, 430 F.2d at 1095.

${ }^{151}$ See Gamer, 430 F.2d at 1095 . The shareholders claimed that the corporation and its officers committed acts "injurious to their interests as stockholders" and that the corporation "was itself damaged by alleged fraud in the purchase and sale of securities." Id.

152 See id. at 1096.

153 Id. at 1097.

154 The court stated: 
the important interests shareholders have in ensuring that corporate management is not abusing its discretion by mismanaging the corporation. ${ }^{153}$

Balancing these competing interests-(1) management's interest in being free from constant second-guessing by dissatisfied shareholders, and (2) shareholders' interest in protecting themselves against corporate mismanagement-the court fashioned a "good cause" exception to the corporate attorney-client privilege. ${ }^{156}$ Thus, a corporation's right to assert the attorney-client privilege against complaining shareholders in litigation is subject to the right of shareholders to show cause why the privilege should not be available in a particular case. ${ }^{157}$

The indicia that were deemed by the court to contribute to a showing of "good cause" tend to track the likelihood of success on the merits of the shareholders' underlying claim. ${ }^{158}$ Thus, if an examina-

Corporate management must manage. It has the duty to do so and requires the tools to do so. Part of the managerial task is to seek legal counsel when desirable, and, obviously, management prefers that it confer with counsel without the risk of having the communications revealed at the instance of one or more dissatisfied stockholders. The managerial preference is a rational one, because it is difficult to envision the management of any sizeable corporation pleasing all of its stockholders all at the time, and management desires protection from those who might second-guess or even harass in matters purely of judgment.

Id. at 1101 . by stating:

${ }^{155}$ The Gamer court emphasized shareholders' competing interests in this regard

But in assessing management assertions of injury to the corporation it must be borne in mind that management does not manage for itself and that the beneficiaries of its action are the stockholders.... There may be many situations in which the corporate entity or its management, or both, have interests adverse to those of some or all stockholders. But when all is said and done management is not managing for itself. ... [M]anagement judgment must stand on its merits, not behind an ironclad veil of secrecy which under all circumstances preserves it from being questioned by those for whom it is,

Id. at least in part, exercised.

\footnotetext{
156 See id. at 1103-04.

157 See id.
}

${ }^{153}$ The indicia that the court listed as contributing to the presence or absence of good cause were:

[T] he number of shareholders and the percentage of stock they represent; the bona fides of the shareholders; the nature of the shareholders' claim and whether it is obviously colorable; the apparent necessity or desirability of the shareholders having the information and the availability of it from other sources; whether, if the shareholders' claim is of wrongful action by the corporation, it is of action criminal, or illegal but not criminal, or of doubtful le- 
tion of preliminary factors tends to demonstrate that discovery of further evidence may prove shareholders' allegations of corporate mismanagement, a judge, at her discretion, should grant discovery of otherwise privileged attorney-client communications. This "good cause" exception to the attorney-client privilege adequately balances the competing interests, for it protects both against shareholder harassment of corporate management which could frustrate the corporate purpose, and mismanagement of corporate power, which is injurious to shareholders.

Subsequent decisions applying the Garner exception to the attorney-client privilege make clear that the need to balance the competing interests discussed by the court is based on the fiduciary relationship that exists between corporate management and shareholders. In Valente v. PepsiCo, Inc., ${ }^{159}$ the court distinguished the facts of Garmer but followed its reasoning in favor of disclosure. ${ }^{160}$ Valente involved a suit by minority shareholders against majority shareholders for federal securities laws violations. ${ }^{161}$ In ordering the disclosure of the information, the court stated that "[a] fiduciary owes the obligation to his beneficiaries to go about his duties without obscuring his reasons from the legitimate inquiries of the beneficiaries." ${ }^{\text {62 }}$ The court in Quintel Corp., N.V. v. Citibank, N.A., ${ }^{163}$ summarized the Gamer holding as follows:

The Gamer rule stems not only from the general proposition that a beneficiary is entitled to know how the authority he has granted has been exercised but on the recognition that because of the mutuality of interest between the parties, the faithful fiduciary has nothing to hide from his beneficiary.

gality; ... the extent to which the communication is identified versus the extent to which the shareholders are blindly fishing; and the risk of revelation of trade secrets or other information in whose confidentiality the corporation has an interest for independent reasons. The court can freely use in camera inspection or oral examination and freely avail itself of protective orders, a familiar device to preserve confidentiality in trade secret and other cases where the impact of revelation may be as great as in revealing a communication with counsel.

Id. at 1104 .

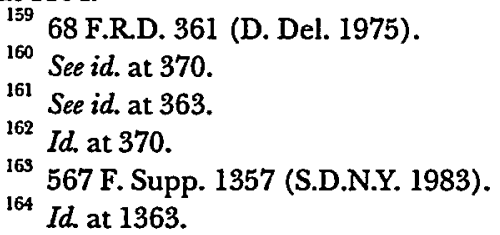


Thus, Garner stands for the proposition that information otherwise free from disclosure may be discoverable when a fiduciary relationship exists between the parties. ${ }^{165}$ The likelihood that the beneficiary's underlying claim against the fiduciary is meritorious, and the need for disclosure from the fiduciary to prove this claim, must be weighed, on a case-by-case basis, against the fiduciary's legitimate interests in nondisclosure. ${ }^{166}$

Implicit in this "good cause" exception allowing discovery of otherwise privileged information is the recognition that, without such discovery, a significant barrier is placed before a beneficiary attempting to prove a breach of a fiduciary relationship. Discovery, therefore, is sometimes necessary to protect beneficiaries from a fiduciary's abuse of her discretionary powers over the beneficiary. In other words, discovery is needed to enforce rights and obligations that, in the absence of discovery, would probably go unenforced.

\section{B. The Application of Garner to a Defendant's Claim of Selective Prosecution}

\section{Prosecutors and Defendants in Fiduciary Relationships}

A prosecutor, like all lawyers, is in a fiduciary relationship with her clients. ${ }^{167}$ This relationship is one of principal and agent, where the client-principal is the beneficiary of the lawyer-agent's conduct. In the prototypical attorney-client relationship, it is clear to whom the attorney owes fiduciary duties. ${ }^{168}$ A prosecutor, however, is not a party to a normal attorney-client relationship; prosecutors represent the

${ }^{165}$ See supra notes 160-64 and accompanying text; see also Sandberg v. Virginia Bankshares, Inc., 979 F.2d 332, 354 (4th Cir. 1992) ("We believe the attorney/client privilege should not be used to shield the communications at the April 20 meeting [the evidence sought by plaintiff-shareholders] from discovery by the very persons for whom the meeting participants were acting as fiduciaries." (emphasis added)); Fausek v. White, 965 F.2d 126, 131 (6th Cir. 1992) (quoting with approval the corporation's assertion that the Gamer rule "stresses 'a requirement of a fiduciary relationship between the parties seeking discovery and the parties resisting compelled [disclosure of] privileged communications"').

${ }_{160}$ See supra notes $156-57$ and accompanying text.

167 See HAZARD ET AL., supra note 143, at 472 (describing the fiduciary model of the lawyer-client relationship and noting that under this model "courts ... look to agency and fiduciary principles to resolve [any] conflict [s]").

${ }^{163}$ The full extent of these fiduciary duties is beyond the scope of this Comment but is summarized by the following quotation: "Lawyers' paramount duties are to their clients: attorneys must pursue client interests zealously, remain loyal at all times, and maintain client secrets." Fred C. Zacharias, Structuring the Ethics of Prosecutorial Trial Practice: Can Prosecutors Do Justice?, 44 VAND. L. REV 45, 53 (1991) (citations omitted). 
government, but the government, in turn, represents the public interest. Following this logic to its ultimate conclusion, one can argue that a prosecutor's clientele is comprised of all the People, including the very defendant she is prosecuting in a particular case:

The prosecutor... enters a courtroom to speak for the People and not just some of the People. The prosecutor speaks not solely for the victim, or the police, or those who support them, but for all the People. The body of "The People" includes the defendant and his family and those who care about him. It also includes the vast majority of citizens who know nothing about a particular case, but who give over to the prosecutor the authority to seek a just result in their name.

One need not, however, take the extreme position that the defendant in the case the prosecutor is trying is part of her clientele. Such a conclusion would present peculiar doctrinal difficulties when a prosecutor is justifiably seeking conviction of a defendant. ${ }^{170}$ Even if a prosecutor ceases to represent a defendant once charges are brought, a prosecutor and a defendant are not typical antagonists in the adversarial system. Unlike in civil litigation where an attorney's function is to seek the best result for her client within the bounds of the law, a prosecutor's recognized duty is not to convict in all cases, but to seek justice. ${ }^{171}$

${ }^{169}$ Carol A. Corrigan, On Prosecutorial Ethics, 13 HASTINGS CONST. L.Q. 537, 538-39 (1986) (emphasis added); Robert P. Lawry, Confidences and the Government Lauyer, 57 N.C. L. REV. 625, 637 (1978) (arguing that a government lawyer works for the public interest and, therefore, must consider her clientele to consist of the public at large); see also Alan B. Morrison, Defending the Government: How Vigorous Is Too Vigorous?, in VERDICTS ON LAWYERS 242, 249 (Ralph Nader \& Mark Green eds., 1976) (noting that even if a government lawyer loses a particular case "their true client [in the lawsuit], the prublic, may win because justice is done" (emphasis added)).

${ }^{170}$ For example, the possibility and/or advisability of prosecutorial loyalty to defendants in the midst of criminal proceedings is at least questionable, if not highly suspect.

${ }^{171}$ The Supreme Court recognized this peculiar duty of prosecutors within the adversary system in Berger v. United States, 295 U.S. 78, 88 (1935) (stating that a prosecutor's interest, as a representative of the government, "is not [to] ... win a case, but [to ensure] that justice shall be done"). The Court elaborated on the balancing in which a prosecutor must engage between seeking a conviction and protecting the rights of the accused:

He may prosecute with earnestness and vigor-indeed, he should do so. But, while he may strike hard blows, he is not at liberty to strike foul ones. It is as much his duty to refrain from improper methods calculated to produce a wrongful conviction as it is to use every legitimate means to bring about a just one.

Id; see also MODEL RULES OF PROFESSIONAL CONDUCT Rule $3.8 \mathrm{cmt} .1$ (1995) (“A prosecutor has the responsibility of a minister of justice and not simply that of an advocate."); MODEL CODE OF PROFESSIONAL RESPONSIBILITY EC 7-13 (1983) (stating that a 
Thus, regardless of whether a defendant is considered part of a prosecutor's clientele, there are duties that prosecutors owe defendants as members of the public at large. ${ }^{172}$ "As a representative of all citizens, the government lawyer actually owes a duty to the opposing party, who is a citizen and a taxpayer and who seeks protection under a law that the government lawyer is committed to uphold." ${ }^{173}$ At a minimum, therefore, prosecutors have duties that are enforceable by defendants, duties which normally do not extend to opposing counsel. These duties arise because prosecutors act for the benefit of the public as fiduciaries of the public interest. ${ }^{174}$ For, although prosecutors retain broad discretion in their capacity as prosecutors, they are "not at liberty to strike foul" blows. ${ }^{175}$ Defendants, thus, have a right

prosecutor's role in the adversarial system "differs from that of the usual advocate; his duty is to seek justice, not merely to convict"); MONROE H. FREEDMAN, LAWYERS' ETHICS IN AN ADVERSARY SYSTEM 85 (1975) (stating that because the government seeks justice, not convictions, "the government wins its point even when a not-guilty verdict is returned").

${ }_{172}$ For a discussion regarding who is the client of a government lawyer, see Beth Nolan, Removing Conflicts from the Administration of Justice: Conflicts of Interest and Independent Counsels Under the Ethics in Government Act, 79 GEO. L.J. 1, 33-43 (1990). Professor Nolan argues that identifying the client as the government lawyer's particular agency most adequately describes the government lawyer's duties. See id. at 41-42. Professor Nolan admits that this model "is incomplete, however, if it means that the [government] lawyer's ultimate loyalty is only to the agency. The government lawyer has obligations to the public interest as well as to the mission of her agency." Id. at 42. Thus, even if a federal prosecutor's client is narrowly defined as the Department of Justice (or even more narrowly defined as her local U.S. Attorney's Office), her duties do not solely extend to her particular government agency, but also to the public at large.

Catherine J. Lanctot, The Duty of Zealous Advocacy and the Ethics of the Federal Government Lawyer: The Three Hardest Questions, 64 S. CAL. L. REV. 951,981 (1991).

${ }^{174}$ The California Court of Appeals described this fiduciary relationship in terms of the agency relationship that defines the attorney-client relationship:

[I]t is true that a public prosecutor, as representative of the People, must satisfy additional standards of conduct by reason of his position as the officer who possesses the power and authority to speak for the State. In practical effect the public prosecutor functions in a dual capacity-as both agent and principal, as both attorney and client. Because he exercises a dual function, the prosecutor possesses additional responsibilities and becomes subject to broader duties than does defense counsel, who only exercises the one function of agent-attorney.

People v. Kelley, 142 Cal. Rptr. 457, 466 (Ct. App. 1977).

${ }_{73}$ Berger, 295 U.S. at 88 . The dichotomy between the broad discretion granted to prosecutors and the duty "not to strike foul blows" is precisely the dichotomy the Garner court was concerned with in fashioning the "good cause" exception to the corporate attorney-client privilege. See Garner v. Wolfinbarger, 430 F.2d 1093, 1103-04 (5th Cir. 1970). A prosecutor needs sufficient discretion in order to "prosecute with earnestness and vigor," Berger, 295 U.S. at 88, just like corporate management needs suffi- 
to be free from improper use of prosecutorial power; and where there is a right there is necessarily a remedy. ${ }^{176}$ Moreover, no right is more fundamental-and in need of a remedy - than a breach of the constitutional guarantee of equal protection of the laws.

\section{The Corporate Mismanagement Analogy}

It is clear that a defendant has a right to be free from overzealous prosecution that amounts to what the Supreme Court has described as "foul [blows]." Moreover, the Court has acknowledged that selecting a person for prosecution based on impermissible criteria, such as race, amounts to a "foul blow," as it is a violation of the basic constitutional right of equal protection of the laws. ${ }^{178}$ Without evidence pertaining to a claim of selective prosecution, which is virtually unobtainable without conducting discovery, ${ }^{179}$ however, a defendant is left with a constitutional right which lacks a realistic remedy. This is because evidence of discriminatory motive is necessary in order to show unconstitutional selective prosecution. ${ }^{180}$

The Garner court confronted a similar situation in the context of a claim of corporate mismanagement. Attorney-client communica-

cient discretion to carry out its obligations. See Gamer, 430 F.2d at 1101 ("Corporate management must manage. It has the duty to do so and requires the tools to do so."). Yet in both situations there exist opposing interests that limit prosecutors' and managements' discretion respectively. In the case of a prosecutor, it is the fact that "[her] duty is to seek justice, not merely to convict," that limits her discretion by placing affirmative duties on her with respect to a defendant. See Berger, 295 U.S. at 88. In the case of corporate management, it is the fact that "it must be borne in mind that management does not manage for itself[,] ... [its] beneficiaries ... are the stockholders," that limits management discretion by placing affirmative duties on it with respect to shareholders. Garner, 430 F.2d at 1101 . Therefore, Gamer supplies a working model for balancing the competing interests present in a situation such as in Armstrong where the defendant believes a prosecutor has struck a foul blow by deciding to prosecute her in federal court rather than leaving prosecution to the state system and its less severe penalties. For a more detailed explanation of the analogy between prosecutorial misconduct and corporate mismanagement, see discussion infra Part III.B.2.

${ }^{176}$ See Marbury v. Madison, 5 U.S. (1 Cranch) 137, 166 (1803) ("[W] here a specific duty is assigned by law, and individual rights depend upon the performance of that duty, it seems ... clear that the individual who considers himself injured, has a right to resort to the laws of his country for a remedy.").

${ }^{177}$ Berger, 295 U.S. at 88.

178 See discussion supra Part I.A-B.

179 See supra text accompanying notes $139-40$ (demonstrating that evidentiary obstacles render a selective prosecution claim virtually unprovable absent discovery because the necessary evidence in proving selective prosecution is invariably in the possession of prosecutors).

${ }^{180}$ See discussion supra Part I.B. 
tions, if discoverable, would have enabled a judge or jury to review meaningfully management's actions for abuse. Absent such discovery, management's decisions would have remained fully protected. But in order for shareholders to be able realistically to enforce their rights, the Gamer court felt it was necessary, when "good cause" was shown, not to allow such vital evidence to remain "behind an ironclad veil of secrecy which under all circumstances preserves it from being questioned by those for whom it is, at least in part, exercised." right to discovery, the court acknowledged, must be tempered by management's legitimate interest in "protection from those who might second-guess or even harass in matters purely of [managerial] judgment. ${ }^{182}$

Armstrong's efforts to obtain discovery of relevant information pertaining to his selective prosecution claim is analogous to the Garner situation. Armstrong had to prove discriminatory motive on the part of federal prosecutors in order to show that his selection for federal prosecution violated the equal protection component of the Fifth Amendment. Realistically, to be able to enforce this constitutional guarantee, discovery of evidence in the sole possession of federal prosecutors would be necessary. ${ }^{183}$ Moreover, federal prosecutors act in the public interest, and the public, including the defendant, has a paramount interest in making certain that prosecutors are not abusing the enormous power they wield. ${ }^{184}$ Prosecutorial judgment, like corporate management judgment should "stand on its merits, not behind an ironclad veil of secrecy which under all circumstances preserves it from being questioned by those for whom it is, at least in part, exercised."

Like the Gamer court acknowledged in the corporate mismanagement context, however, the interests to be protected by discovery must be balanced with a prosecutor's interest in nondisclosure. ${ }^{186}$ Just as "[c]orporate management must manage," prosecute. Therefore, prosecutors' legitimate desire to be protected against defendants who are likely to "second-guess or even harass"

\footnotetext{
${ }^{181}$ Garner v. Wolfinbarger, 430 F.2d 1093, 1101 (5th Cir. 1970).

${ }^{182} I d$.

I8s See supra note 139 and accompanying text.

${ }^{184}$ See supra note 72 and accompanying text.

185 Gamer, 430 F.2d at 1101. 
them on matters legitimately within prosecutorial discretion, demonstrates a need to temper freely granted discovery with ironclad veils of secrecy. ${ }^{189}$ Had the Court in Armstrong adequately addressed the discovery issue by balancing the competing interests of defendants, who seek to protect their equal protection rights, with those of prosecutors, who seek to effectively enforce federal criminal law, it would have established a "good cause" exception to the doctrine of prosecutorial discretion. This exception would have been similar to the "good cause" exception to the attorney-client privilege fashioned by the Gamer court. Yet the Armstrong Court did not adequately balance the analogous interests balanced by the court in Garner; rather the Court preserved an ironclad veil of secrecy by setting a "significant barrier" before defendants seeking discovery on selective prosecution claims. $^{190}$

\section{A "Good Cause" Exception to Prosecutorial Discretion and the Federal Charging Decision}

The Garner court listed several factors that a court should consider in determining whether shareholders had shown the "good cause" required to overcome the attorney-client privilege in a specific case. ${ }^{191}$ These factors can be divided into three categories: (1) statistical indicia of the merits of the shareholders' underlying claim; ${ }^{192}$ (2) the relative importance of the right asserted to have been breached by management in the litigation; ${ }^{193}$ and (3) affirmative reasons for nondisclosure. ${ }^{194}$ Each of these categories can guide a court in determining whether discovery should be granted relating to an analogous claim of selective prosecution in the federal charging decision. These factors are not meant to be an exhaustive list of the relevant indicia of good cause. They are merely meant to guide judges in determining, at a very preliminary stage of a selective prosecution claim, whether the claim is clearly frivolous or has the requisite merit to war-

${ }^{189}$ See id.

190 See United States v. Armstrong, 116 S. Ct. 1480, 1486 (1996).

191 See supra note 158 and accompanying text.

192 This category includes the number of shareholders involved as plaintiffs in the litigation along with the percentage of stock they represent. See id.

${ }_{193}$ This category relates to whether the underlying claim asserts management engaged in criminal activity, illegal but not criminal activity, or activity of doubtful legality. See id.

See id.

${ }^{194}$ This category includes the fear of revealing any trade secrets through discovery. 
rant further discovery. The final determination of good cause should be made by the district judge acting within her discretion to order discovery and should only be reversed if the judge has abused this discretion. ${ }^{195}$

\section{Statistical Indicia of Racial Bias}

The national statistical data showing extreme discriminatory impact of federal crack criminal enforcement is stark and troublesome in two senses. First, most defendants in federal crack cases are black, and second, the correspondingly disproportionate number of white crack offenders being prosecuted in state court are subject to more lenient penalties. ${ }^{196}$ Of course, these national data do not necessarily correspond to the statistics in each district, and therefore this factor will not automatically support a discovery request relating to a selective prosecution claim in all judicial districts. What is important, nonetheless, is that defendants can obtain these statistics absent discovery; and at the least, these data call into question the motivations of the particular district's U.S. Attorney's Office in making its federal charging decisions. ${ }^{107}$ Consequently, the statistics strengthen defendants' claims for further discovery related to federal prosecutors' charging criteria that would either prove race-based selective prosecution or vindicate the constitutionality of the prosecutor's charging decision.

Other easily obtainable threshold statistical data that would be relevant to a court's determination of whether there is good cause to

193

Cf. United States v. Armstrong, 116 S. Ct. 1480, 1492 (1996) (Stevens, J., dissenting) (arguing that the Ninth Circuit's decision upholding the district court's discovery order was correct because the district judge had not abused her discretion in ordering discovery despite the fact that Justice Stevens would not have ordered discovery if he had been the district judge in Armstrong (citing United States v. Armstrong, 48 F.3d 1508, 1520-21 (9th Cir. 1995) (Wallace, C.J., concurring) (stating that the applicable standard of review when reviewing a district court's discovery ruling is abuse of discretion))).

${ }^{196}$ See supra note 68 and accompanying text. The data concerning the racial makeup of crack offenders being prosecuted in state court is very preliminary due in large part to the failure of most states to distinguish between crack-cocaine and powder cocaine, as the federal system does. See Days, supra note 68, at 188-89 (noting that only three states were able to provide the U.S. Sentencing Commission with the racial makeup of defendants in state crack prosecutions because of the failure of most states to make the crack/powder cocaine distinction and arguing that a 50-state study is needed).

${ }^{197}$ See supra notes 59, 69-70 and accompanying text; see also United States v. Armstrong, 48 F.3d 1508, 1513 (9th Cir. 1995) (noting that statistical disparities alone may establish a prima facie case of selective prosecution). 
grant discovery on a defendant's selective prosecution claim involve the particular facts of the case before the court. For example, a drug prosecution involving a federal law enforcement investigation, a repeat offender, a large quantity of drugs, multiple sales, or a firearm would tend to support the government's assertion that the case was being brought federally for race-neutral reasons. When such aggravating circumstances are present, federal prosecution provides for added punitive and deterrent effects. ${ }^{198}$

\section{Importance of the Right Being Asserted}

Equal protection of the laws has been a fundamental right protected by the Constitution since Reconstruction. ${ }^{199}$ Moreover, the right to be free from selective enforcement of a facially neutral statute based on race was recognized to be within the ambit of the Equal Protection Clause over a century ago in Yick Wo v. Hopkins. ${ }^{200}$ A criminal defendant's right to protection against racially discriminatory initiation of proceedings that will potentially take away her liberty is as important a right as any guaranteed by the Constitution. ${ }^{201}$ This does not, however, mean that this second category of indicia of good cause will always support granting discovery. The injury in an Armstrong-like situation is not that the defendant is being prosecuted at all, but that

198 Interestingly, all these factors would tend to support the government's contention in Armstrong that the federal charging decision was not motivated by race, despite the statistics showing disproportionate racial impact of federal charging decisions in the Central District of California. See Days, supra note 68, at 184 (noting that the Armstrong case involved more than twice the quantity of crack necessary for mandatory tenyear sentences under federal law, due to multiple sales indicating a large crack distribution ring, multiple federal firearm violations, and criminal histories for some of the defendants); see also Armstrong, $116 \mathrm{~S}$. Ct. at 1483 (including with these facts that federal law enforcement agencies as well as local police were involved in the arrest of the defendants). These facts suggest that perhaps Armstrong was a fairly weak case factually to come before the Supreme Court on such an important issue. See id. at 1492 (Stevens, J., dissenting) (agreeing with the majority that Armstrong's "showing was not strong enough to give [him] a right to discovery," but arguing that the "District Judge did not abuse her discretion when she concluded that the factual showing was sufficiently disturbing to require some response from the United States Attorney's Office"); $c f$. Kirk A. Kennedy, Thurgood Marshall's Enduring Legacy: A Prescription for the 1990s Public Interest Lawyer, 38 How. L.J. 383, 397-401 (1995) (reviewing MARK V. TUSHNET, MAKING CIVIL RIGHTS LAW: THURGOOD MARSHALL AND THE SUPREME COURT, 1936-1961 (1994), and noting the importance Thurgood Marshall placed on finding sympathetic plaintiffs in his litigation campaign to abolish de jure segregation).

${ }^{199}$ See U.S. CONST. amend. XIV, § 1.

${ }^{200} 118$ U.S. 356, 373-74 (1886); see also discussion supra Part I.A.

201 See supra note 87 and accompanying text; see also discussion supra Part II.B.1. 
she is being prosecuted in federal court subject to more severe federal penalties. The level of the disparity in sentences that exists between the federal and state system depends on a number of factors, most notably the applicable state law. The less disparity there is between the applicable federal sentencing range and the applicable state sentencing range, the less likely it is that prosecutors are deciding to proceed federally based on race. Moreover, as noted above, the existence of more severe federal penalties might be a race-neutral reason in and of itself for proceeding federally. Therefore, a court should not consider the importance of the right at stake in isolation from the facts of the particular case.

\section{Affirmative Reasons for Nondisclosure}

To preserve maximum effectiveness in law enforcement's efforts to combat the drug problem in this nation, a U.S. Attorney's Office has a strong interest in maintaining the confidentiality of certain information. ${ }^{202}$ As the Gamer court stated in addressing the analogous need for confidentiality of such corporate information as trade secrets, if a judge is concerned with the negative effects that public disclosure of certain prosecutorial material may have on law enforcement efforts, the court can order in camera inspection of relevant information with accompanying protective orders to ensure secrecy. ${ }^{203}$ If the judge, acting in her discretion, believes such mechanisms would not adequately protect law enforcement effectiveness, this factor would support denying a discovery request.

A set barrier prohibiting discovery on the federal charging decision in the context of a selective prosecution claim does not balance the competing interests present. What is needed is a model for the trial judge to follow so that these competing interests will be balanced on a district-by-district, case-by-case basis. The balancing model established by the Fifth Circuit in Garner is exactly such a model. Given the analogous policies discussed in Garner, that court's balancing test is similarly appropriate for courts to use in determining whether discovery is appropriate in Armstrong-like claims of selective prosecution in the federal charging decision.

${ }^{202}$ See discussion supra Part II.B.3.

${ }^{203}$ See Garner v. Wolfinbarger, 430 F.2d 1093, 1104 (5th Cir. 1970); see also supra note 117 and accompanying text. 


\section{CONCLUSION}

"Federal prosecutors are respected members of a respected profession. Despite an occasional misstep, the excellence of their work abundantly justifies the presumption that 'they have properly discharged their official duties." ${ }^{204}$ Justice Stevens, however, continued in his Armstrong dissent by recognizing that "[n] evertheless, the possibility that political or racial animosity may infect a decision to institute criminal proceedings cannot be ignored." ${ }^{205}$ It is this possibility that the Court in Armstrong ignored, and has been the focus of this Comment. Unlike prior selective prosecution cases that have been decided by the Supreme Court, ${ }^{206}$ Armstrong dealt only with the possibility of selective prosecution in the case before the Court, not the reality of selective prosecution in the particular case. Yet by injecting the rigorous standard necessary to prove selective prosecution into the standard necessary to obtain evidence of selective prosecution, the Court has effectively shut the courthouse door to defendants claiming unconstitutional selective prosecution, especially in an area of particular concern, namely, federal crack prosecutions. The Armstrong decision leaves defendants attempting to prove selective prosecution in an evidentiary Catch-22 that effectively removes from the Constitution a major component of equal protection. Until a model is established that provides for meaningful judicial review of prosecutorial discretion in the selective prosecution context, as the fiduciary model does, perhaps it will take "[a]nother hundred years ... before a defendant demonstrates to the Court's satisfaction that race played a role in his prosecution. Given our country's history, however, it seems unlikely that race will not influence any prosecutions in that time. ${ }^{207}$

204 Armstrong, 116 S. Ct. at 1492 (Stevens, J., dissenting) (quoting United States v. Chemical Found., Inc., 272 U.S. 1, 15 (1926)).

${ }^{205}$ Id. (emphasis added) (citing Oyler v. Boyles, 368 U.S. 448, 456 (1962)).

${ }^{206}$ See, e.g., Wayte v. United States, 470 U.S. 598 (1985); Oyler v. Boles, 368 U.S. 448 (1962); Yick Wo v. Hopkins, 118 U.S. 356 (1886).

${ }_{207}$ Leading Cases, supra note 23 , at 174. 